
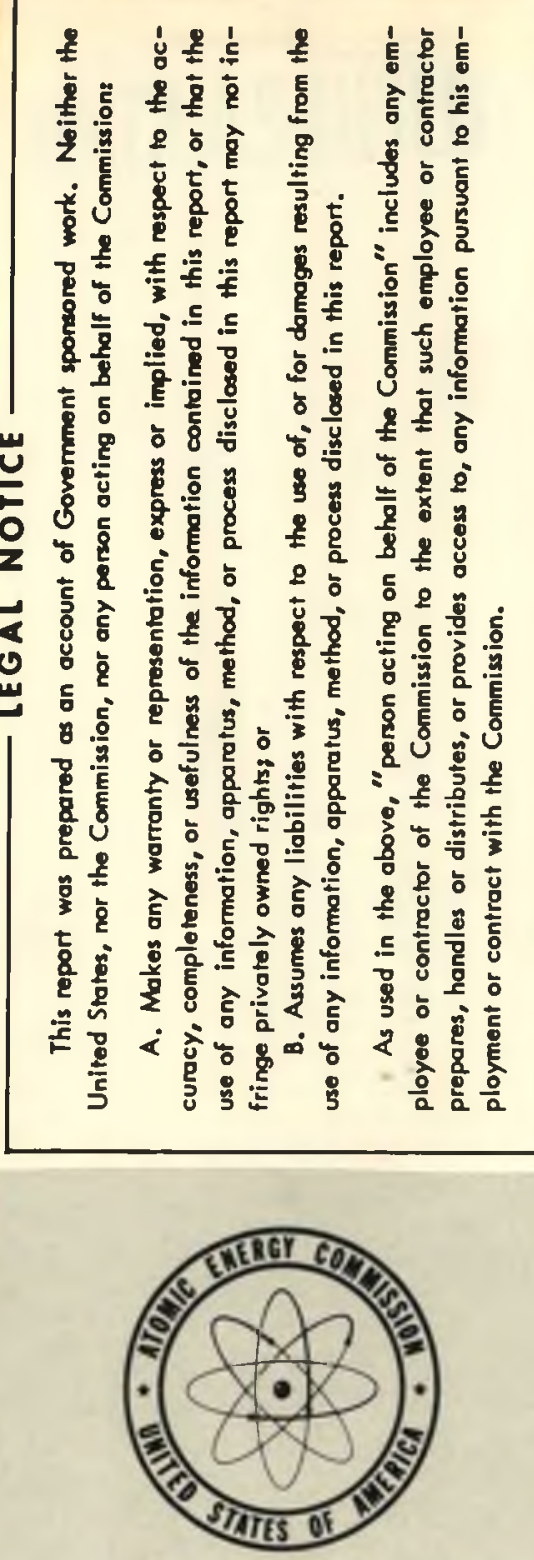

UNITED STATES ATOMIC ENERGY COMMISSION

REACTOR DEVELOPMENT QUARTERLY

PROGRESS REPORT. 4000 PROGRAM-

By

Stuart McLain

Price $\$ 0.45$

Available from the

Office of Technical Services

Department of Commerce

Washington 25, D. C.

October 31,1955

Argonne National Laboratory

Lemont, Ilinois

Technical Information Extension, Oak Ridge, Tennessee 


\section{… CONFIDENTIAL}

This report has been revlewed under the Declassification Guide of 1955.

\section{LEGAL NOTICE}

Thls roport wos prepored as an eceount of Unitad States, nor the Commission, nor any a

A. Makes any warronty or reproser euroey, completeness, or usefulneus $e^{\prime}$ use of any informatlon, apporatus fringe prlvately awnad rightile

B. Astumas any llablli"! use of eny Information, $\theta$.

Al und in the $r^{\circ}$ ployee or contres, prepares, handies or 4 outes, or provldas seeass to, eny information punuent to hls om ployment or contreat with the Commlusion.
Iment iponsored work. Neither the . on behalf of the Commissioni

ress or Impllad, with respeet to the oecoflon centolned in this report, or that the a proeen diselosed in this roport may not in-

seef to the use of, or for damages resulting from the sthod, or process diselosed In this report. .con oapling on bohalf of the Commiculon" Includes any emCommisclon to the extent that sueh omployee or contractor

Th1 report ha been reproduoed directly from the beot avellable oopy.

Printed in USA. Charge 45 oenta. Available from the Technical Information Ixtons 10n, P. O. Box 1001, Ouk Ridge, Tonnossee. Plowse droot to tho samo addross Inquiries coporing the procuroment of olawsifiod AnC roports. 
ANL-5514(Del.)

ARGONNE NATIONAL LABORATORY

P. O. Box 299

Lemont, Illinois

Classification cancelled (or changed to UNCLASSIFIED

by authority of Form AEC- 381 .

by C.P.Boqqess TiE, date $11-18-57$

QUARTERLY PROGRESS REPORT ON

REACTOR DEVELOPMENT

4000 PROGRAM

as of

October 31,1955

Compiled by members of the Laboratory Staff and Stuart McLain, Program Coordinator

Published, February, 1956

ANL-5398 November, December, 1954 - January, 1955

ANL-5438 February, March, April, 1955

ANL-5476 May, June, July, 1955

Operated by The University of Chicago

under

Contract W-31-109-eng-38

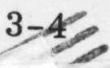


$$
\text { . }
$$ 


\section{DISCLAIMER}

This report was prepared as an account of work sponsored by an agency of the United States Government. Neither the United States Government nor any agency Thereof, nor any of their employees, makes any warranty, express or implied, or assumes any legal liability or responsibility for the accuracy, completeness, or usefulness of any information, apparatus, product, or process disclosed, or represents that its use would not infringe privately owned rights. Reference herein to any specific commercial product, process, or service by trade name, trademark, manufacturer, or otherwise does not necessarily constitute or imply its endorsement, recommendation, or favoring by the United States Government or any agency thereof. The views and opinions of authors expressed herein do not necessarily state or reflect those of the United States Government or any agency thereof. 


\section{DISCLAIMER}

Portions of this document may be illegible in electronic image products. Images are produced from the best available original document. 


\section{TABLE OF CONTENTS}

I. EXPERIMENTAL BOILING WATER REACTOR

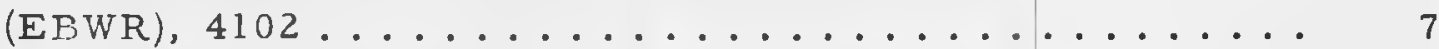

A. Alternate Methods of Operation of EBWR ......... 9

1. Forced Circulation $-\mathrm{H}_{2} \mathrm{O} \ldots \ldots . . . \ldots 10$

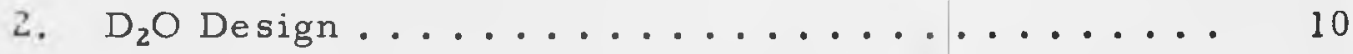

B. Fabrication of Zircaloy-Clad Fuel Elements........ 12

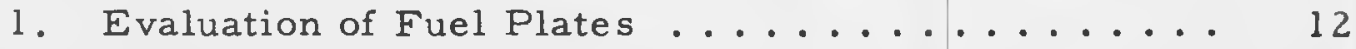

2. Casting $\mathrm{U}-5 \% \mathrm{Zr}-1.5 \% \mathrm{Nb} \ldots \ldots . . \ldots 13$

3. Equipment for Manufacturing Fuel Elements..... 14

4. Measurement of Clad Thickness ............ 14

5. Fabrication of EBWR Subassemblies ......... 14

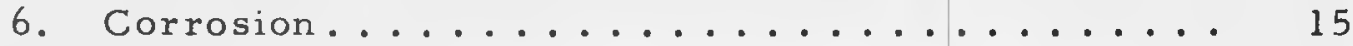

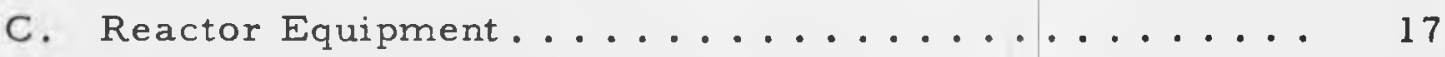

1. Inner Thermal Shield ................. 17

2. Support and Containment Structure ......... 18

3. Reactor Water Purification System .......... 18

4. Feed Water Make-Up System ............. 20

5. Radioactive Carry-over in the Steam ......... 20

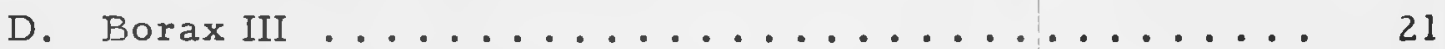

II. FAST POWER BREEDER REACTOR, $4104 \ldots . \ldots 22$

A. EFR-II Working Model Tests ................ 22

1. Control Rod and Cover Mechanisms ......... 22

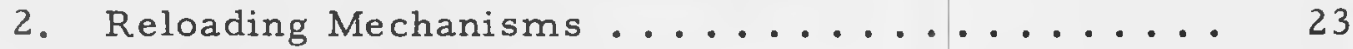

3. d-c Electromagnetic Pump ................ 24

B. Decay-Heat Cooling Requirements ............ 24

C. Irradiation Tests of EBR-II Pir-Type Fuel Elements ... 24

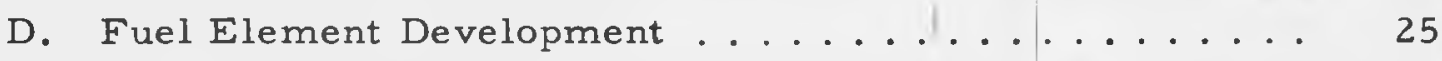

1. Thermalcycling of U-Mo and U-Zr Alloys...... 25

2. Properties of U-Pu-Mo Alloys ............ 26

3. Effects of Irradiation on Extruded U-Pu Alloys .... 29

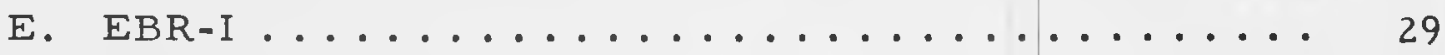

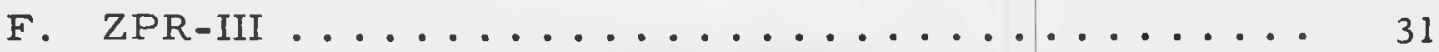


TABLE OF CONTENTS

Page

III. REACTOR TECHNOLOGY DEVELOPMENT, 4500

B. Metallurgical Development .............. 33

1. Epsilonized U-3.8\% Si Alloy ........... 33

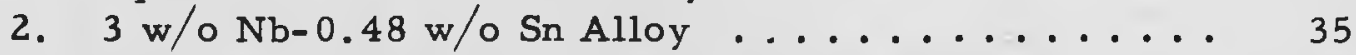

3. Effects of Irradiation on U-Powder Compacts ..... 35

4. Properties of Urania-Thoria Bodies ......... 35

5. Effects of Irradiation on $\mathrm{UO}_{2}$ Specimens ....... 38

6. High Temperature Corrosion Resistant Alloys .... 38

7. Inspection of $800^{\circ} \mathrm{C}$ Na Loop Welds .......... 44

C. Development of Shielding and Control Rod Materials ... 46

D. Remote Control Development . . . . . . . . . . . 47

1. Electric Discharge Machine, Model 1. ....... 47

2. Optical Glass Study ................ 47

3. Force-Reflecting Servomechanisms ......... 47

IV. ASSOCIATED ENGINEERING AND DEVELOPMENT 4600.2 . 49

A. Fluoride Volatility Process Research . . . . . . . . . 49

B. Chemical Metallurgical Separations Research ........ 49

C. Fluidization Studies ................. 50

D. Process Waste Disposal and Utilization .......... 50

\section{OONFHEEIIAH}


QUARTERLY PROGRESS REPORT ON

REACTOR DEVELOPMENT

4000 PROGRAM

I. EXPERIMENTAL BOILING WATER REACTOR (EBWR), 4102

The steel cylinder or shell in which the EBWR will be built has been erected. Leakage tests will be made to verify that the leakage rate is less than $500 \mathrm{ft}^{3}$ per day at $15 \mathrm{psig.} \mathrm{After} \mathrm{leakage} \mathrm{and} \mathrm{pressure} \mathrm{testing,} \mathrm{open-}$ ings will be cut in the shell for access and installation of airlocks.

The major pieces of power generating equipment have either been received or are expected in the near future.

The design of support and containment features for the reactor has been completed. Very heavy vertical steel columns imbedded in the concrete base and biological shield, and tied together by cross beams above the reactor, will be used to prevent portions of the pressure vessel from being blown upward as a result of the high pressure gases which could conceivably be produced from chemical reactions between molten core metals and water. The maximum explosion would relieve itself by rupturing the lower part of the pressure vessel and shattering the shield at the sides and bottom of the reactor. The gas-tight steel building is protected from missile damage by its 2 -ft thick concrete lining.

A complete control rod and mechanical drive mechanism combination is being tested under the geometrical, temperature, and pressure conditions anticipated in the EBWR. Although some sticking of the control rod, due to foreign particles in the small clearance between ring seals and shaft, has been observed, this type of drive mechanism is expected to be satisfactory after minor modifications. Other types of rod drives are being investigated also. These include: (1) mechanical drives with rotating rather than sliding seals; (2) hydraulic, floating piston-type drivers; and (3) magnetic jack drives. The EBWR design is such that different rod drives can be substituted after the reactor has been operated, if this proves to be desirable.

The flexibility being built into the EBWR to permit future operation with forced circulation and conversion to $\mathrm{D}_{2} \mathrm{O}$ reactor has required changes and additions to the pressure vessel and shield. A borated steel thermal shield inside the pressure vessel is a necessity for operation with $\mathrm{D}_{2} \mathrm{O}$. Without such a thermal shield the secondary $\gamma$ radiation created by capture of leakage thermal neutrons in the walls of the pressure vessel would create 
excessive thermal stresses. Experimental batches of stainless steel containing $1 \%$ or móre $\mathrm{B}$ have been prepared by a number of industrial concerns. Corrosion resistance is good, and ductility is adequate for use in thermal shields.

The design of the reactor shield has been completed and materials are being ordered. A 1/2-in. layer of ferroboron cement plaster will be applied to the outside surface of the $\mathrm{Pb}$ thermal shield. This will reduce radioactivation of structural materials and of the air surrounding the pressure vessel. In the radial direction, the ferroboron plaster will be followed by a 5-ft thickness of magnetite concrete and $3 \mathrm{ft}$ of ordinary concrete. Dense concrete containing steel punchings will be used below the reactor and a combination of steel and $\mathrm{H}_{2} \mathrm{O}$ will be used above the reactor. Removable magnetite concrete blocks will be placed in those portions of the biological shield traversed by piping. This feature will be a convenience during initial construction and will make subsequent removal of the pressure vessel mechanically feasible. No cooling will be provided for the concrete blocks, as the estimated maximum temperature of $120^{\circ} \mathrm{C}$ is not expected to be unduly detrimental.

Inasmuch as the heat treatments required for the $\mathrm{U}-5 \% \mathrm{Zr}-1.5 \%$ $\mathrm{Nb}$ fuel alloy to achieve dimensional stability and corrosion resistance appear to be incompatible, emphasis has been placed on dimensional stability and clad integrity. This has introduced the possibility of eliminating the $\mathrm{Nb}$ constituent. It was found, however, that the decreased hardness of the U-Zr alloy aggravated plate rolling problems. The corrosion rate is also increased enormously. Nb appears to be a worthwhile, even though expensive, ingredient of the EBWR fuel.

Sample, natural U plates have been made to EBWR specifications. No defects were found in corrosion tests in $288^{\circ} \mathrm{C}$ water. The techniques for making fuel plates and mounting them in assemblies, appear to be satisfactory.

Cost estimates by industrial concerns for fabricating enriched $U$, "spike" plates for EBWR were much higher than anticipated. As a result, slightly enriched fuel, $1.44 \%$, and natural $U$ will be used. A small number of natural $U$ assemblies will be required to take care of uncertainties in the required enrichment even for the slightly enriched case.

The problem of detecting cladding failures in EBWR fuel plates continues to be a formidable one. Calculations indicate that the existence of a failure somewhere in the core can be detected by radiation monitoring of the exhaust gases from the main power plant condenser, but no simple method for quickly determining which fuel plate has failed is evident. Mock-up tests have shown that radioactivity quickly disperses throughout the core, thereby making it difficult, if not impossible, to determine by radioactivity measurements the cooling channel from which the fission products originated. 
In view of the scarcity and high cost of $\mathrm{Hf}$, alternate materials for control rods are under development. One type of control rod has a mixture of sintered $\mathrm{Gd}$ and $\mathrm{Sa}$ oxides packed in a hollow stainless steel can. Boronstainless steel alloys also show promise.

Further corrosion tests on $\mathrm{Al}-\mathrm{Ni}$ alloys show low corrosion rates in stagnant neutral water. At high velocities of water flow, the corrosionerosion increases but the rate is reduced in slightly acidic water. Evidence exists that excess hydrogen inhibits corrosion. Six-month tests have been started at $316^{\circ} \mathrm{C}$ and above.

Tests are being performed to determine the influence of boiling heat transfer on the corrosion rates of Zircaloy II and Al-Ni surfaces. No conclusive results are yet available.

Clad specimens of $\mathrm{ThO}_{2}$ containing $10 \%$ of enriched $\mathrm{UO}_{2}$ have been irradiated in $260^{\circ} \mathrm{C}$ water to burnups between 0.05 and $0.3 \mathrm{a} / \mathrm{o}$. Postirradiation examinations showed varying degrees of fracturing of the cylindrical ceramic specimens, perhaps indicating excessive thermal stresses. No damage to the cladding was observed. Results of boiling heat transfer tests in both single and multiple cooling channels with forced and natural circulation have indicated that correlations of different boiling heat transfer channels can be predicted in advance. This work will require considerable checking before publication.

\section{A. Alternate Methods of Operation of EBWR}

It is obvious that significant gains in the specific power of boiling reactors can be achieved with forced circulation. It is believed that greater stability and safety may be reached with a $\mathrm{D}_{2} \mathrm{O}$-moderated and cooled boiling reactor along with greater economy in the larger sizes planned for eventual central station power plant use. For this reason, the present EBWR design, which has been based as an $\mathrm{H}_{2} \mathrm{O}$ natural circulation reactor, has been modified in order to permit future experimentation with both forced circulation and $\mathrm{D}_{2} \mathrm{O}$ operation. In order to achieve these goals, components which cannot be changed in the system, such as the reactor vessel and shielding, are designed to meet the requirements of all the above types of operation.

The vessel and shielding design necessary for the multipurpose requirements are virtually complete, as mentioned above. However, the design of the core structure, fuel elements, and control rods (except for the rod penetration pattern) have only been carried far enough to assure that the present system can be adapted to future plans. 


\section{Forced Circulation $-\mathrm{H}_{2} \mathrm{O}$}

The change to forced circulation will be accomplished by placing a circular shroud around the core support plate. This shroud will seat on a machined ring on the bottom head of the pressure vessel and will be bolted down to the support plate to form an inlet plenum chamber. The coolant will enter the chamber through four 6-in. nozzles located outside the control rod nozzles, and will flow up through the core area defined by the dummy fuel elements and possibly by a circular shroud ring around the core. The recirculated water will then flow down outside the shroud and out of the vessel through two 12-in. outlet nozzles located opposite each other just above the bottom head of the vessel. Auxiliary use will be made of three of the nozzles for connection of the ion-exchange system, highpressure injection system, and startup heater system for the reactor vessel.

When the change to forced circulation is made, the nozzle flanges will be connected by a manifold system and led out of the sub-reactor room to a pump area outside the lower extension of the outer ordinary concrete biological shield. The number and nature of the pumps have not yet been established; however, the total pumping capacity will be approximately $10,000 \mathrm{gpm}$ with a maximum head of less than $100 \mathrm{ft}$. A reasonably low pressure head, approximately $5-15 \mathrm{ft}$, will be required. With these specifications the present EBWR core should deliver about 30-35 $\mathrm{mw}$ at the same void fraction as $20-\mathrm{mw}$ natural circulation operation. However, since an improvement in reactor stability should be achieved with forced circulation, the average operating steam void fraction may be increased and a total reactor power in excess of $40 \mathrm{mw}$ may be feasible.

The more significant aspects of forced circulation will be realized in operation with a smaller core diameter. The available pumping head should be sufficient to increase the coolant velocity through the core by a factor of at least 4 with an average steam void fraction in excess of $20 \%$. Under these conditions the reactor power density could be increased possibly five-fold over the natural circulation value of about $26 \mathrm{kw} / \mathrm{liter}$ of coolant. At these high power densities the burnout heat flux factor would be limiting for the present fuel elements.

\section{2. $\mathrm{D}_{2} \mathrm{O}$ Design}

$\mathrm{D}_{2} \mathrm{O}$ reactors have always been attractive for large scale power producers, primarily because of high neutron economy. Moreover, the large neutron lifetime is attractive from the standpoint of safety and stability, the latter being particularly important for boiling operation. In order to evaluate the effect of $\mathrm{D}_{2} \mathrm{O}$ in a boiling reactor, the EBWR system is designed to handle a $40-\mathrm{mw} \mathrm{D}_{2} \mathrm{O}$ core of size similar to the present $\mathrm{H}_{2} \mathrm{O}$ core. Both the thermal and biological shielding have been designed to meet the more stringent requirements of the $\mathrm{D}_{2} \mathrm{O}$ reactor shielding. 
Present specifications on permissible leakage from the external system are adequate for use of $\mathrm{D}_{2} \mathrm{O}$. The fuel handling coffin and shielding for fuel element removal have also been designed for the higher power density in the fuel and for the lack of a water shield above the core during fuel inspection and unloading.

Every item within the reactor vessel in which a change might be required in order to permit revisions in core structure, core position, and fuel assembly, has been designed to be removable and replaceable. Only the locations of control rod penetrations through the lower head of the reactor vessel are unchangeable. The latter does not appear to be a serious limitation since there are a number of lattice arrays that can be located in the present control rod pattern. Specifically, the items that may undergo a change in size, shape, and location are:
a. Lower support plate;
b. Fuel element and assemblies;
c. Control rods and guides.

Additions which will be required in any case are:

a. Process tubes around fuel assemblies to separate the fuel zone from moderator zone.

b. Upper support plate (boron-stainless steel in part) to align process tubes and to shield the upper portion of the reactor vessel walls from heating because of thermal neutron capture $\gamma$ rays.

Certain aspects of the $\mathrm{D}_{2} \mathrm{O}$ design have been established:

a. Natural circulation does not appear worthwhile because of the lower resultant core power density in a lumped fuel-type reactor. The $\mathrm{D}_{2} \mathrm{O}$ core would have somewhat less than half the volume filled with fuel elements, and hence the core power density may only be $10-15 \mathrm{kw} /$ iter of core with natural circulation. A $500-\mathrm{mw}$ core would require a volume of about 33,000-50,000 liter,s, or roughly a core $12 \mathrm{ft}$ diam and $12 \mathrm{ft}$ high without reflector, if a 10-15 kw/liter power density could be applied to a $12-\mathrm{ft}$ high core. Actually, it is believed that the maximum power output of a natural circulation channel is only slightly dependent on its height once above 2-4 ft, and hence the core power density of a $12-\mathrm{ft}$ high core may only be $4-6 \mathrm{kw} /$ liter.

b. In a boiling $\mathrm{D}_{2} \mathrm{O}$ reactor, the void fraction for a given steaming rate and the void coefficient in the moderator are high. Therefore, the sudden creation of voids in the moderator (possibly as the result of a small reduction in pressure) can shut the reactor down to such an extent that there is considerable potential for initiation of an excursion when 
the voids collapse. For this reason it is desirable to operate with the moderator slightly subcooled. This may easily be achieved, in forced circulation operation, by passing a fraction (10\% maximum) of the circulated coolant directly into the moderator space, with the fuel element coolant separated from the bulk of the moderator. The shroud designed for the $\mathrm{H}_{2} \mathrm{O}$ forced circulation will be adequate for separating the moderator zone of the $\mathrm{D}_{2} \mathrm{O}$ reactor from the downcomer area.

c. The present $\mathrm{H}_{2} \mathrm{O}$ design has too much stainless steel close to the top and bottom of the active core to utilize the benefits from $\mathrm{D}_{2} \mathrm{O}$ as a reflector in these directions. If the axial $\mathrm{D}_{2} \mathrm{O}$ reflector is desired, it will be necessary to replace the stainless steel structure with $\mathrm{Zr}$ for at least $1 \mathrm{ft}$ above and below the core, to increase the distance between the support plate and the active core, and to drive the control rods a greater distance out of the top of the core for the "full out" position.

d. The present fuel assemblies are adequate, but not ideal, for a $\mathrm{D}_{2} \mathrm{O}$ design because of plate thickness and excessive metal-to-water ratio. A new fuel element consisting of thinner plates and less metal per unit volume would enhance the performance.

\section{B. Fabrication of Zircal̨oy-Clad Fuel Elements}

A sufficient number of plates have been prepared to complete the development of $\mathrm{U}-5 \% \mathrm{Zr}-1.5 \% \mathrm{Nb}$ alloy cores roll clad with Zircaloy II. Additional data were obtained from plates scaled to the size of the EBWR fuel elements to establish the correct billet design and dimensional tolerances for finish rolled plates.

Binary U-Zr alloys considered as possible alternates for the EBWR reference ternary alloy were roll clad with Zircaloy II using procedures developed for the reference alloy. Increasing the $\mathrm{Zr}$ in the alloy from 5 to $7 \frac{1}{2}$ and $10 \mathrm{w} / 0$ improved the uniformity of the rolled plate and cladding. Two clad plates of $\mathrm{U}-5 \% \mathrm{Zr}$ proved to be defective when corrosion tested in $290^{\circ} \mathrm{C}$ water. Binary clad plates with $7 \frac{1}{2}$ and $10 \mathrm{w} / 0 \mathrm{Zr}$ have not been evaluated.

\section{Evaluation of Fuel Plates}

A total of 27 integrally clad plates of the EBWR reference alloy clad with Zircaloy II were rolled and physically evaluated for uniformity, core distribution, and bond quality. These included plates scaled to the size of the EBWR fuel elements to establish the effects of steel jacket variables on plate dimensional uniformity. Plates which were 0.250 in. nominal thickness, and some of 0.280 in. nominal thickness, were prepared for subassembly testing. 
A comparison between 21 clad plates rolled in plain C steel jackets and 6 plates rolled in Ti-Namel (Ti-killed steel) jackets showed no measurable difference in bond quality or cladding uniformity. Prior corrosion testing in $290^{\circ} \mathrm{C}$ water of plates rolled in plain C steel jackets showed no detrimental effects from the steel. As a result of these corrosion tests no advantage could be attributed to the use of Ti-Namel steel jackets. Physical measurements of width spread on rolling showed that EBWR type billets rolled in $\mathrm{Ti}-\mathrm{Namel}$ jackets spread only 1.5 to $4.0 \%$ as compared with 3.0 to $6.5 \%$ when rolled in plain C steel jackets of the same size. Width spread may be compensated for in the design of billets making it possible to roll plates to a predetermined size in either Ti-Namel or plain C steel jackets.

Although Zr-tipped Zircaloy II screwed plugs provided a satisfactory seal for purge-welded and evacuated billets, frequently the plate ends as rolled contained continuous or segmented inclusions around the original screwed plug. A redesigned tapered seal plug was substituted for the screwed plug on six billets. Metallographic examination showed very few segmented inclusions at the seal plug to end plug interfaces.

\section{Casting $\mathrm{U}-5 \% \mathrm{Zr}-1.5 \% \mathrm{Nb}$}

The production of satisfactory $\mathrm{U}-5 \% \mathrm{Zr}-1.5 \% \mathrm{Nb}$ castings for manufacture of EBWR fuel plates has proven to be exacting. Desirable cores must be homogeneous in alloy distribution and free of shrinkage and blowholes. The mold used for 17 castings was $1 \frac{1}{4} \mathrm{in}$. by $11 \frac{1}{2} \mathrm{in}$. in cross section by $35 \mathrm{in.}$ deep and was suitable for 7 EBWR cores. Gross defects such as cold shuts, large surface blowholes, and large areas of shrinkage on the sides of the castings were eliminated after three or four castings were made. The alloying irregularities and the imperfections revealed by ultrasonic testing have not been removed completely from the castings. The last two castings showed defects in the top $7 \mathrm{in}$. for 2 cores, but the botton 18 in. for 5 cores of each casting were sound. Both of the alloying elements, $\mathrm{Zr}$ and $\mathrm{Nb}$, were segregated from top to bottom and from center to edge in these castings, with the $\mathrm{Zr}$ and $\mathrm{Nb}$ contents higher at the top than at the bottom, and higher in the center of the casting than at the edges. The above castings were made in a $20-i n$. ID quartz tube furnace. The induction coil outside of the quartz tube was $23 \mathrm{in.} I D$. The graphite crucible was $14 \mathrm{in}$. OD by 11 in. ID.

Six castings were made from a newly designed threecavity graphite mold. The cavities were separated by graphite plates so that each cavity was $1 \frac{1}{4} \mathrm{in}$. by $3 \frac{1}{2} \mathrm{in}$. in cross section by $24 \mathrm{in}$. deep. Each cavity was designed to produce two EBWR cores. The mold was designed for bottom filling - that is, the metal was poured into the central cavity and bottom gated into the two side cavities. Sound castings were not obtained by this procedure and the mold has been changed so that all three 
cavities are filled by top pouring. While the castings made by bottom filling were unsound due to secondary pipe, they were quite homogeneous in alloy distribution. These castings were made in a 12 -in. quartz tube furnace which had a $14-i n$. ID induction coil and an 8 in. ID by $9 \frac{1}{4} \mathrm{in.}$ OD graphite crucible. The far greater inductive coupling of the metal obtained in this furnace is considered to be primarily responsible for the homogeneous alloy distribution in these castings.

\section{Equipment for Manufacturing Fuel Elements}

Most of the facilities required for the manufacture of the EBWR fuel plates have been installed and tested. Some existing equipment was relocated and altered, and additional equipment was obtained to handle billet component cleaning, billet assembly, roll cladding, and heat treatment of finished plates. These modifications were necessary to manufacture fuel plates on a projected schedule of 10 to 12 per 8 -hour day.

\section{Measurement of Clad Thickness}

The attenuation of the $\beta$ radiation emitted by $\mathrm{Pa}^{234}$ (a second daughter of $\mathrm{U}^{238}$ ) can be used to measure clad thickness of EBWR fuel elements. A scintillation detector is used to detect the $\beta$ radiation after it has passed through the cladding material. The scintillating material is an anthracene disk of $1-i n$. diam.

Three EBWR-type fuel elements were scanned. Variations in the clad thickness of the three plates were observed. Strips of stainless steel of 2 -in. width were glued to the plates and the attempt was made to detect their presence as artificial variations in the clad thickness. It was concluded that with a scanning speed of $4 \mathrm{in} . / \mathrm{min}$ a variation of 0.0005 in. thickness of clad could be detected in sections of 2 -in. width or wider; at a scanning speed of $24 \mathrm{in.} / \mathrm{min}, 0.003-\mathrm{in}$. variation could be detected. With the adjustments as described, these gave a change in the output which was clearly above statistical variation. With a scanning speed of $24 \mathrm{in.} / \mathrm{min}$, a 0.005 -in. variation in widths of $2 \mathrm{in}$. is easily seen. For the faster scanning speed it was found desirable to reduce slightly the time constant of the counting rate meter. Choice of scanning speed depends upon sensitivity desired and time available.

\section{Fabrication of EBWR Subassemblies}

A semiautomatic welding device, which will permit inert arc spot welding of Zircaloy II-clad EBWR subassemblies in a sealed, Hefilled chamber, is now being constructed. This machine is expected to be capable of welding a minimum of two subassemblies per eight-hour day. 


\section{Corrosion}

a. $\mathrm{U}-5 \% \mathrm{Zr}-1.5 \% \mathrm{Nb}$ Alloy $-\mathrm{H}_{2}$ Studies

Corrosion tests designed to correlate corrosion damage and $\mathrm{H}_{2}$ absorption in the $\mathrm{U}-5 \% \mathrm{Zr}-1.5 \% \mathrm{Nb}$ alloys have been made. A relatively high $\mathrm{H}_{2}$ content, e.g., $35 \mathrm{ppm}$ as found in a sample quenched from salt at $850^{\circ} \mathrm{C}$, is not detrimental to corrosion resistance in the asquenched condition. This may be due to the uniform distribution of the $\mathrm{H}_{2}$.

A group of samples which had been quenched from salt were aged for various times at $400^{\circ} \mathrm{C}$ in the $\alpha$ phase and tested for $71 \mathrm{hr}$ in degassed distilled $\mathrm{H}_{2} \mathrm{O}$ at $290^{\circ} \mathrm{C}$. The aging times bracketed that for optimum corrosion resistance of a vacuum-treated sample, i.e., approximately $2 \mathrm{hr}$. The results are shown in Table I. The as-quenched sample acted in the normal, expected fashion. The aged samples corroded in a completely different fashion than do vacuum, heat-treated and similarly aged metal.

Table I

EFFECT OF AGING ON CORROSION RESIST ANCE AND

$\mathrm{H}_{2}$ ABSORPTION OF U-5\% $\mathrm{Zr}-1.5 \% \mathrm{Nb}$ ALLOY

AS-CAST - QUENCHED FROM SALT AT $850^{\circ} \mathrm{C}$

\begin{tabular}{cccc}
$\begin{array}{c}\text { Aging } \\
\text { Time at } \\
400^{\circ} \mathrm{C}, \mathrm{hr}\end{array}$ & & $\begin{array}{c}\text { Corrosion } \\
\text { Rate, mcd }\end{array}$ & $\begin{array}{c}\mathrm{H}_{2} \text { Content } \\
\text { of Alloy } \\
\text { after Test, } \\
\text { ppm }\end{array}$ \\
\cline { 1 - 1 } 1 & & $\begin{array}{c}13.5 \\
337 *\end{array}$ & 382 \\
2 & & $450 *$ & 1220 \\
3 & $616 *$ & 1340 \\
4 & - & - \\
\hline & *Based on remaining piece
\end{tabular}

It is believed that the aging process causes the $\mathrm{H}_{2}$ to concentrate, perhaps at grain boundaries. This concentration may act as a nucleus for further rapid $\mathrm{H}_{2}$ absorption. It is significant that this is the first instance in which very small pieces of metal close to cracked surfaces 
have been analyzed. Very high $\mathrm{H}_{2}$ contents were found, as had been previously postulated. Unfortunately, the remnants of the corrosion tests were not large enough to permit both $\mathrm{H}_{2}$ analysis and metallography. The series of heat treatments will be repeated and the samples examined before corrosion testing.

\section{b. Powder Metallurgy}

Preliminary results of corrosion tests of samples prepared at Sylvania by powder metallurgy techniques indicate that during heat treatment a longer time in the $\gamma$ region is required than for cast metal. These results also indicate that mild aging improves corrosion resistance as compared with conventionally prepared metal.

\section{c. Effect of Irradiation on Corrosion}

Two completely clad plates were tested at indicated burnups of 0.021 and $0.079 \mathrm{a} / \mathrm{o}$, respectively. Both samples were from the same standard type clad plate. Exposed core ends and edges were weld clad with Zircaloy II. The samples were water quenched after $15 \mathrm{~min}$ at $850^{\circ} \mathrm{C}$ and aged at $425^{\circ} \mathrm{C}$ for $45 \mathrm{~min}$. After irradiation, a $1 / 8$-in. diam hole was drilled through the clad to the core of each sample.

One sample was tested in degassed, distilled water for $58 \mathrm{hr}$ between 240 and $275^{\circ} \mathrm{C}$. At the end of this period there was loose oxide at the hole but no swelling. A second sample was similarly tested for $66 \mathrm{hr}$ at $290^{\circ} \mathrm{C}$. At the end of this period the undrilled cover plate was almost completely severed from the assembly, being attached at one corner only. The drilled cover plate was not as completely separated. There was no swelling of the cover plate at the drilled hole. All failures were along welds. The core swelled to at least twice its original thickness and was apparently completely converted to oxide.

A sample duplicate in every respect to the second sample except that it was not irradiated was tested at $290^{\circ} \mathrm{C}$ for $95 \mathrm{hr}$. There was no change except difference in color between core and clad.

Additional irradiated samples will be tested. However, it appears certain that even irradiation to low burnup destroys the corrosion resistance of this alloy.

\section{d. Corrosion Tests of Zircaloy II-Clad U-5\% Zr Plates}

Since heat treatment for stability and heat treatment for corrosion resistance were found incompatible, it was decided to heat treat for stability and to depend on the clad for corrosion resistance. Because the $\mathrm{Nb}$ had been added in the first place to improve corrosion resistance, elimination of corrosion resistance as a specification of the core 
alloy apparently eliminated the need for $\mathrm{Nb}$, a very expensive ingredient. To test this hypothesis, some plates were made with $\mathrm{U}-5 \% \mathrm{Zr}$ core and clad with Zircaloy II. The alloy was found to be much more difficult to fabricate than the U-5\% $\mathrm{Zr}-1 \frac{1}{2} \% \mathrm{Nb}$ reference alloy. Several of these plates were tested in $288^{\circ} \mathrm{C}$ degassed water. After $70 \mathrm{hr}$ a pressure buildup indicated a rupture, and the test was stopped. Visual examination showed that the shrinkage pattern delineating the picture frame area had been emphasized as a result of the corrosion test. Ultrasonic tests indicated that the corrosion test had aggravated some defects in the core and bond areas. The blister which occurred on one plate was attributed to the use of an end plug of $\mathrm{Zr}$, instead of Zircaloy II, which resulted in a non-corrosion resistant bond that permitted water to enter and produce the blister.

The poor behavior of these plates, both during fabrication and in corrosion test, indicates that the U-5\% $\mathrm{Zr}$ core alloy is not as good as the reference $\mathrm{U}-5 \% \mathrm{Zr}-1.5 \% \mathrm{Nb}$ alloy.

\section{e. Zircaloy II - Stainless Steel Contact Corrosion}

Contact-corrosion test specimens of Zircaloy II bolted to Types 304 and 347 stainless steels have accumulated a total of $5672 \mathrm{hr}$ in dynamic (10 fps), degassed, demineralized water $\left(1470 \mathrm{hr}\right.$ at $260^{\circ} \mathrm{C}$ and $4202 \mathrm{hr}$ at $316^{\circ} \mathrm{C}$ ). Static corrosion tests on duplicate specimens in airsaturated and in degassed water have accumulated a total of $5212 \mathrm{hr}$ at $260^{\circ} \mathrm{C}$ and $5850 \mathrm{hr}$ at $316^{\circ} \mathrm{C}$. No contact or crevice effects are detectable.

\section{Reactor Equipment \\ 1. Inner Thermal Shield}

The projected use of the EBWR facility with $\mathrm{D}_{2} \mathrm{O}$ as the moderator and coolant magnifies the shielding problems considerably, since $\mathrm{D}_{2} \mathrm{O}$ is a very poor neutron absorber. The design of the biological shielding provides for future operation with $\mathrm{D}_{2} \mathrm{O}$. The $\mathrm{D}_{2} \mathrm{O}$ core has also dictated the thermal shield requirements to protect the pressure vessel from excessive thermal stresses due to $\gamma$ heating. A stainless steel, 1-w/o B thermal shield, 1 in. thick, will keep the thermal stress to 1600 psi. Recent development work by steel suppliers indicates that $1 \%$ B-contained stainless steel will be available at a lower cost than the required thickness of ordinary stainless steel of $6 \mathrm{in}$. The samples received thus far are strong and ductile; however, irradiation and corrosion data are not yet available.

The cylindrical portion of the thermal shield is $9 \mathrm{ft}$ high with a horizontal ring around the top which projects inward to a point 6 in. from the vessel wall. The $\mathrm{D}_{2} \mathrm{O}$ core will have an upper fuel element support consisting of a horizontal flat plate of B-stainless steel, 1 in. thick by $5 \mathrm{ft}-10 \mathrm{in}$. diam, about $2 \mathrm{ft}$ above the core surface. This plate will 
act in combination with the ring as a shadow thermal shield for the upper portion of the vessel. This combination is necessary to prevent serious restriction of the downcomer annulus. The lower portion of the vessel is shielded by a conical section of B-stainless steel, $1 \mathrm{in}$. thick, and by the lower core support plate.

\section{Support and Containment Structure}

The pressure vessel support structure must serve the dual purpose of supporting the vessel under both normal static and abnormal impact conditions, such as accidental dropping of pieces of heavy equipment on the vessel, and of containing any missiles which might be launched as the result of a violent metal-water chemical reaction within the reactor core.

Two sets of three parallel builtup Carilloy T-1 columns are anchored in the reinforced concrete below the reactor and extend upward to the top of the pressure vessel. Three parallel builtup Carilloy $\mathrm{T}-1$ holddown beams span a 6-in. thick missile and biological shield and are connected to the two sets of vertical columns with removable wedges. The columns are protected from the full lateral force of an explosion of the core by two blast shields made up of 1 -in. steel plates and 3 -in. layers of redwood and Celotex. The pressure vessel is supported from the top of the columns on a flexible structure made up from Carilloy $\mathrm{T}-1$ beams. C-shaped springs have been placed between the pressure vessel mounting lugs and the support structure as added insurance against damage in case a piece of heavy equipment is dropped on the pressure vessel.

\section{Reactor Water Purification System}

After an extensive study of the water systems of the various operating reactors was made, it was decided that no water treatment as such would be applied to the reactor water, at least for the initial operation. Operational performance and experience may indicate the need for some type of treatment to minimize corrosion and entrainment in the steam.

The reactor system will be initially filled with deionized water, not deaerated, having a specific resistance of 6 megohms, total solids being about $0.2 \mathrm{ppm}$. It is imperative that the total solids, both soluble and insoluble, of the reactor water be kept at a minimum to prevent: (1) deposition of soluble and insoluble constituents from reactor water to heat transfer surfaces, and (2) excessive radioactivity buildup in the turbine and condenser system and reactor auxiliary components, i.e., steam drier, startup heater, feed-water pumps, valves, and piping. The preventive measures include: (a) full-flow filtration of condensate, and (b) a continuous bypass purification loop. 
a. Full-flow Filtration of Condensate

Two "Fulflo" filters of 180 -gpm capacity each are in parallel between the reactor feed-water pumps and the reactor vessel. Each unit contains 75 cotton thread filter cartridges, resulting in a moderate loading of $2.4 \mathrm{gpm}$ per cartridge. Laboratory tests have indicated that at this loading no difficulty should arise from excessive pressure drop due to packing of the cotton threads. Normally only one unit will be in operation. The second unit will be a standby which will be switched into the system when the differential pressure across the operating unit reaches a predetermined value indicating clogging of the filter surfaces.

The cotton thread filter cartridges are capable of removing particulate matter down to 2 to 5 micron size. It is difficult to predict what percentage of the corrosion-erosion products from the turbinecondenser system will be retained in the filter. Utility power plant operation indicates between 25 to $50 \%$ of the $\mathrm{Fe}$ in the condensate is in the insoluble form. However, the particle size distribution is not known and the greater percentage probably is in colloidal form or consists of particles less than one micron. There is the possibility that the cotton fibers will absorb or exchange colloidal corrosion products and metallic ions such as $\mathrm{Fe}^{++}$and $\mathrm{Fe}^{+++}$.

No attempt has been made to determine the radioactivity level that will be attained in the filter units but it should not be high. Because of the expected low activity level, these units will not have integral shielding. If the activity level does increase to a high level, temporary shielding will be installed.

Removal of the "hot" filter cartridges is facilitated by having the filter cartridges in a removable cage assembly. The entire assembly will be lifted from the vessel and placed in a container for removal and ultimate disposal.

\section{b. By-pass Purification Loop}

The by-pass purification loop has a three-fold purpose: (1) to maintain reactor water quality of $1-$ megohm specific resistance, equivalent to 0.5 to 1.0 total solids; (2) to afford primary cleanup of reactor system after a fuel plate failure; and (3) to supply normal shutdown cooling facility.

The quality of the reactor water will be maintained at $1-$ megohm specific resistance by continuous recirculation of a maximum of $10 \mathrm{gpm}$ through the purification loop. The flow rate necessary to maintain the above water quality was calculated, using the corrosion data supplied by Allis-Chalmers, to be less than $5 \mathrm{gpm}$. These corrosion data were for 
an Admiralty Metal-tubed condenser. Because of the change to Al condenser tubes - subsequent to the sizing of the loop - the $5-\mathrm{gpm}$ value is probably high and the actual flow rate through the loop will probably be less than $5 \mathrm{gpm}$.

The loop will be operated at a maximum flow rate following a fuel plate failure in an attempt to remove the major portion of the contamination - U, Pu, and fission product oxides and soluble compounds.

\section{Feed Water Makeup System}

Two mixed-bed ion exchange units, 10-gpm, 6000-gallon capacity, will supply demineralized water, not deaerated, having a specific resistance of 6 megohms and a pH of 7.0. The total solids will be below $0.2 \mathrm{ppm}$. A $10-\mathrm{gpm}$ "Fulflo" filter unit will be placed in each of the effluent discharge pipes to protect against carry-over of resin fines or extraneous material into the reactor water system.

\section{Radioactive Carry-over, in the Steam}

The amount of radioactivity carried over to the turbine and condenser system depends on the extent of entrainment in the steam of soluble and insoluble solids and volatile constituents in the reactor water. The actual amount of entrainment has been checked by experiments using tracer activity in boiling high purity water. The carry-over is strongly affected by the presence of dissolved impurities accumulated during boiling. However, decontamination factors of from $10^{4}$ to $10^{5}$ are consistently obtained on water containing $\mathrm{Cs}^{137}$ tracer.

Tests are under way extending this investigation to Borax III. Early indications are that decontamination factors of the same order of magnitude will be obtained.

Calculations of activity that will be carried over into the turbine during normal operation were made, using a decontamination factor of $1 \times 10^{3}$ to be on the pessimistic side; the results indicated that shielding of turbine or condenser will not be necessary.

Conditions will be entirely different following a fuel plate failure. No attempt has been made to calculate the resulting activity levels in the external steam system. All of the fission product gases and possibly $50 \%$ or so of the $\mathrm{I}_{2}$ released by the fuel during corrosion will be carried over into the turbine by the steam. Most or all of the $I_{2}$ is expected to condense somewhere in the turbine and either "plate" out on the turbine or condenser internals or be dissolved by the wet steam and returned to the reactor vessel in the condensate. The fission product gases are expected to be drawn out 
of the system through the air ejector and be discharged to the atmosphere through the reactor building vent. A high efficiency filter will be placed in the exhaust line to trap any particulate matter which may be inadvertently carried over.

\section{Borax III}

The full power operation of Borax III during the last quarter indicated certain changes and modifications in the system. More shielding was needed in the reactor building over both the pump pit and the reactor. Removable concrete blocks were made for these areas and installed. A new exhauster and stack were added for ventilating the reactor compartment. This is now maintained under negative pressure with respect to the building. The ion chamber openings ran at a temperature above that allowable for coaxial cables and the insulation in use. A water cooling system was added to keep this temperature within the allowable range.

The packing glands sealing the control rod shafts through the pressure vessel lid were located in an area which was inaccessible except after a long term shutdown. This area was also high enough in radiation that the Teflon packings suffered damage and had to be replaced. Extensions and new packing glands were fabricated to bring these up through the first shield section where these troubles would not be encountered.

A standby gasoline driven generator and an air compressor were installed for use during power outages.

A fuel element was inspected by removing it from the core and examining it under water with the aid of binoculars. While a heavy coating had been built up on the surface of the Al, no severe corrosion was noticeable.

The major problem which has shown up is the control of the water so as to maintain conditions for a low Al corrosion rate. The $\mathrm{pH}$ of the reactor water tends to go basic, whereas it is desired to have the water acid. The next period of operation will be devoted to various schemes for keeping the water under control. 


\section{FAST POWER BREEDER REACTOR 4104 \\ A. EBR-II Working Model Tests}

The tank of the quarter-scale model of the reactor was first degreased and, following field installation of the test components, particulate matter was removed from all metal surfaces with a vacuum cleaner. No attempt was made to chemically clean the metal surfaces of the tank to remove adsorbed gases and oxides before filling. Only those cleaning techniques were used which could be employed practically in a large field installation.

After filling with approximately 5,000 gal of $\mathrm{Na}$, the $\mathrm{Na}$ surface was covered by an unbroken dull grey coating. The $\mathrm{Na}$ temperature was then raised from the filling temperature of $150^{\circ} \mathrm{C}$ to $290^{\circ} \mathrm{C}$ and cold-trapping operations were begun. After ten hours of cold trapping, the dissolved $\mathrm{O}_{2}$ content of the tank $\mathrm{Na}$ was $0.002 \mathrm{w} / \mathrm{O}$ and the $\mathrm{Na}$ surface still retained the grey coating. After $75 \mathrm{hr}$ the $\mathrm{Na}$ surface was mirror bright and the dissolved $\mathrm{O}_{2}$ concentration was $0.001 \mathrm{w} / \mathrm{o}$.

It is believed that the initial grey coating on the $\mathrm{Na}$ was in the form of oxide. The two probable sources of this oxide were $\mathrm{O}_{2}$ impurities in the $\mathrm{A}$ atmosphere and $\mathrm{Na}$ reactions with adsorbed gases and oxides on the metal surfaces. The experimental evidence indicates that the rate of solution of this oxide film is the limiting process in the system cleanup in that the dissolved $\mathrm{O}_{2}$ concentration was reduced to less than $0.002 \mathrm{w} / 0$ by cold trapping while the oxide surface film still existed. It is possible that higher operational temperatures would result in more complete wetting of the oxide by $\mathrm{Na}$, thus increasing its rate of solution. This, with the increase in saturation concentration of $\mathrm{Na}_{2} \mathrm{O}$ in $\mathrm{Na}$ at high temperatures, would reduce considerably the cold-trapping time necessary to clean up a closed $\mathrm{Na}$ system.

\section{Control Rod and Cover Mechanisms}

The control rod and the cover raising and rotating mechanisms were installed and initially tested inside the empty and unheated primary tank. The tank was then filled with He and the temperature of the tank increased periodically until the temperature of the gas was raised to $296^{\circ} \mathrm{C}$. All mechanisms performed satisfactorily under these conditions. The primary tank was then filled with $\mathrm{Na}$, leaving an 18-in. gas blanket. Performance tests were then conducted concurrently with periodic increases in temperature until a $\mathrm{Na}$ temperature of $371^{\circ} \mathrm{C}$ was reached.

The control rod-operating mechanism performed satisfactorily, with the exception of the sensing device which began to stick at $204^{\circ} \mathrm{C}$. At this temperature the dial pointer could be moved by exerting a slight 
pressure on the pointer. Movement of the sensing device became more difficult with increased temperature and it finally stuck completely at $260^{\circ} \mathrm{C}$.

Upon dismantling the mechanism, the sensing shaft was found to be colored dark blue by the high temperature and the presence of oil was detected on the shaft. There was also an accumulation of oil and broken particles of graphite from one of the bushings. The shaft showed no signs of galling or roughening of the surface. It is assumed that the wedging of graphite particles between the shaft and bushing, coupled with the burning of the oil on the shaft by the high temperature, caused the sensing shaft to stick. The faulty conditions were corrected by removing the units and by increasing clearances between moving parts. The cover raising and rotating mechanism performed satisfactorily throughout the test.

\section{Reloading Mechanisms}

The operation of the fuel reloading system in the empty and unheated primary tank was checked first and the tank temperature raised step-wise up $296^{\circ} \mathrm{C}$. It was observed that the components worked progressively harder as the temperature increased, and galling occurred between several of the stainless steel surfaces. To improve these conditions, clearances on the gripper, transfer arm, and the bottom parts of the fuel elements were increased. The hold-down tubes extending downward from the reactor shield cover were removed also. After these adjustments were made the primary tank was filled with $\mathrm{Na}$, leaving the 18-in. gas blanket, noted above. Performance tests were conducted while the $\mathrm{Na}$ temperature was gradually increased to $371^{\circ} \mathrm{C}$.

The fuel reloading equipment was operated in the $\mathrm{Na}$ for 30 reloading cycles. The following conditions were noted: (1) after reaching $370^{\circ} \mathrm{C}$ misalignment of the reactor vessel with the rotating plugs was noticed; (2) the open jaws of the gripper mechanism did not always release the fuel rod, due to misalignment: (3) $\mathrm{Na}$ was siphoned inside the bellows of the shaft seal; (4) difficulties occurred in transferring fuel rods because of the differential thermal expansions in the parts of the transfer arm and storage rack; and (5) increased friction on the sealing surface of the large rotating plug stalled the drive motor.

It was decided to lower the $\mathrm{Na}$ temperature to allow for removal and readjustment of some of the plugs and mechanisms before continuation of the performance tests. All parts of the reloading mechanism were disassembled, reworked to increase clearances, and reassembled. During the disassembling, the $\mathrm{Na}$, although frozen, became severely oxidized. On startup the oxide was successfully removed by cold trapping for a few days. 


\section{3. d-c Electromagnetic Pump}

The d-c electromagnetic pump designed to test the feasibility of operating a pump completely submerged in the primary Na coolant has been operated successfully in the EBR-II Working Model.

The pump is located in the tank in a circuit which includes an electromagnetic flowmeter, pressure transmitter, and throttling valve.

The pump has been operated at 30,000 amperes (design is 50,000 amperes) with an ambient $\mathrm{Na}$ temperature of $370^{\circ} \mathrm{C}$. The performance of the pump when submerged in $\mathrm{Na}$ was somewhat better than that obtained when the pump was tested in a closed pipe loop. This may have been due to lowered amounts of gas trapped in the $\mathrm{Na}$.

\section{B. Decay Heat Cooling Requirements}

After full-power operation of the EBR-II reactor to $1 \%$ burnup of the fuel, the irradiated fuel subassemblies will be allowed to decay in the reactor storage racks for two weeks. At this time, the subassemblies that received the highest burnup will be generating about 2300 watts of decay heat.

An electrically heated model of a reference design fuel assembly was constructed to simulate the decay heat after removal from the storage rack. The 91 elements were inserted in a reference hexagonal subassembly tube and mounted in a vertical position. Provision was made so that a blast of cooling air or argon gas could be metered into the bottom of the assembly.

The first test consisted of determining the heat dissipation from the assembly in air without forced cooling. At a power of 261 watts ( $11 \%$ of expected power), the hottest element had an equilibrium temperature of $530^{\circ} \mathrm{C}$. Air at the rate of $9.41 \mathrm{ft}^{3} / \mathrm{min}$ was introduced into the bottom of the assembly and the power adjusted to 2330 watts. Under these conditions, a maximum fuel tube surface temperature of $563^{\circ} \mathrm{C}$ was obtained. The air outlet temperature was $444^{\circ} \mathrm{C}$, indicating an air temperature rise of $422^{\circ} \mathrm{C}$, accounting for $90 \%$ of the heat input. With a heat input of 2265 watts and an argon gas flow of $12.2 \mathrm{ft}^{3} / \mathrm{min}$, a maximum temperature of $536^{\circ} \mathrm{C}$ was obtained. The argon outlet temperature was $453^{\circ} \mathrm{C}$, indicating an argon temperature rise of $443^{\circ} \mathrm{C}$, accounting for $96 \%$ of the heat input.

\section{Irradiation Tests of EBR-II Pin-Type Fuel Elements}

Three facilities are now available in the CP-5 reactor for the irradiation of EBR-II pin-type fuel elements. To date five elements have been placed under irradiation. 
Irradiation Test No. 1 is complete. At an average burnup of $0.38 \mathrm{a} / \mathrm{o}$, a portion of the fuel pin had dissolved a portion of the stainless steel cladding tube.

Test No. 2 was terminated after a total irradiation time of $1316 \mathrm{hr}$, corresponding to an estimated average burnup of $0.38 \mathrm{a} / \mathrm{o}$. The approximate maximum fuel temperatures at reactor operating power and at higher power reactor safety checks were $538^{\circ} \mathrm{C}$ and $621^{\circ} \mathrm{C}$, respectively. The element accumulated 195 thermal cycles. Post-irradiation inspection showed the fuel to have reacted with the cladding tube in the uppermost region, damage being greatest at the top and extending downward approximately 2 in. The remainder of the fuel appeared to be in excellent condition, showing some surface roughening only at the bottom section.

Complete penetration of the stainless steel tubing occurred in the damaged region. Removal of this tubing disclosed a clean, white $\mathrm{Na}$ surface extending from below the damaged section to the bottom of the fuel.

The type of damage noted does not necessarily indicate a poor fuel element. For irradiation, the assembled element was placed in a finned capsule with a 20-mil annulus of $\mathrm{Na}$ provided for heat transfer. In Test No. 2 only enough $\mathrm{Na}$ was provided to place the level at the top of the fuel element. When the finned capsule was opened, considerable $\mathrm{Na}$ was found in a region 2 to 3 in. above this point. Since cooling air enters at the top of the test assembly there is a region where freezing of $\mathrm{Na}$ is possible. Enough $\mathrm{Na}$ in this position would prevent complete bonding in the annulus around the fuel, giving a most reasonable explanation for the type of damage received.

An examination of the irradiated rods indicated grain coarsening, gross bumping, and surface distortion on part of the slugs.

\section{Fuel Element Development}

1. Thermalcycling of U-Mo and U-Zr Alloys

A group of powdered metallurgy specimens, fabricated by Sylvania Electric Products, were thermalcycled in NaK to determine the relative stability of U-Mo and U-Zr alloys. Some wrought and heat treated U-2\% Zr specimens, fabricated at Argonne, were included as a basis for comparison. Of particular interest was the effect produced by cycling above the $\alpha-\beta$ transformation temperature of unalloyed $U$.

All specimens were 2.3 in. long by $0.144 \mathrm{in}$. diam. The powdered metallurgy specimens were in the as-sintered condition. The samples prepared at Argonne were swaged to size and heat treated. The 
stabilizing heat treatment consisted of heating the swaged specimens at $800-810^{\circ} \mathrm{C}$ for $8 \mathrm{~min}$. and furnace cooling in vacuo $\left(5 \times 10^{-5} \mathrm{~mm} \mathrm{Hg}\right)$. Time lapse in cooling from $800^{\circ} \mathrm{C}$ to room temperature was $11.3 \mathrm{hr}$.

To obtain the information desired, 4 specimens of each type were used. Two specimens from each set were given 200 cycles from 65 to $620^{\circ} \mathrm{C}$, the high $\alpha$ region. The remaining specimens were given 200 cycles from 90 to $715^{\circ} \mathrm{C}$, the $\beta$ region. Holding time at each temperature was $3 \mathrm{~min}$, with a $10-\mathrm{sec}$ transition between temperatures. All specimens of a given group were cycled together to obtain identical cycling conditions.

Figure 1 shows the composition, grain size, and appearance of one $\alpha$ - and one $\beta$-cycled specimen of each type. The table at the bottom of this figure lists the average per cent change of length, weight, and density for each set of specimens. Magnified views of the surface condition of all specimens are shown in Fig. 2 .

As expected, all $\alpha$-cyeled specimens showed little distortion. The $\beta$-cycled $\mathrm{Zr}$ alloys exhibited considerable distortion, whereas the Mo alloys appeared to be unaffected. There was some change in the surface condition of these alloys with decreasing Mo content, as shown in Fig. 2; however, no cracking or surface bumping was evidenced. The thermalcycling stability of the low Mo alloys make them attractive for applications where operation, or cycling, of the fuel in the $\beta$ region is contemplated, provided their irradiation damage resistance is satisfactory.

\section{Properties of U-Pu-Mo Alloys}

Several castings of nominal composition U-21\% Pu-5\% Mo were made. Pouring temperatures in the range $1510-1525^{\circ} \mathrm{C}$ yielded a fluid pour, but because of turbulence, porosity was not entirely eliminated. The casting densities obtained were 17.7, somewhat less than the theoretical density of 18.4 as calculated from X-ray data. Casting hardness was in the range 67.5-72.5 $\mathrm{R}_{\mathrm{A}}$. Fracture grain size indicated fine grain material, corroborated by metallographic examination. Machinability was roughly equivalent to that of the binary $U-P u$ alloy. X-ray diffraction showed the structure to be $\mathrm{BCC}$ with $\mathrm{a}_{0}=3.42 \AA$. However, results of thermal expansion tests indicate that this phase is probably metastable. On repeated cycling in the apparatus an arrest point developed in the vicinity of $530^{\circ} \mathrm{C}$. After three cycles an irreversible elongation of $0.02 \mathrm{in}$. per inch remained. Most of this elongation occurred above $530^{\circ} \mathrm{C}$; the maximum temperature reached was $713^{\circ} \mathrm{C}$. Below the transformation temperature the heating and cooling curves were roughly parallel corresponding to $\alpha=18 \times 10^{-6}$.

This material was not workable by rolling at $400^{\circ} \mathrm{C}$. Rolling with unheated rolls at preheat temperature of $675^{\circ} \mathrm{C}$ permitted approximately 
A - ALPHA CYCLED. 200 CYCLES FROM $150 \mathrm{~F}$ TO $1150 \mathrm{~F}$

B - BETA CYCLED. 200 CYCLES FROM $200 \mathrm{~F}$ TO $1320 \mathrm{~F}$

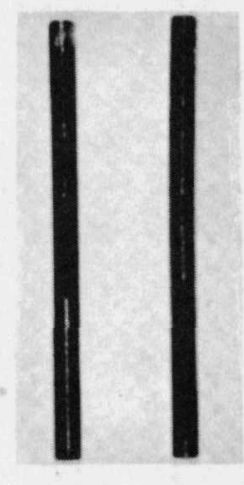

SPECIMEN

\section{ANALYSIS}

GRAIN SIZE,

microns

ELONG., \%

WT. CHG., \%

DENS ITY

DECREASE, \%

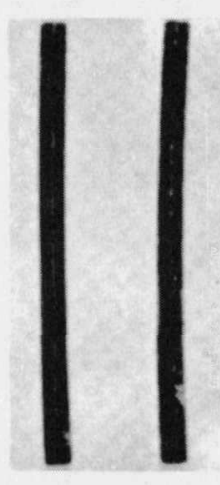

$2 \mathrm{~A} \quad 2 \mathrm{~B}$

$2 \% \mathrm{MO}-\mathrm{U}$

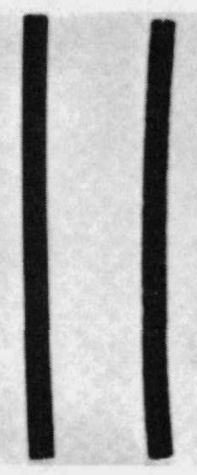

$3 A \quad 3 B$

1. $4 \% \mathrm{Mo}-\mathrm{U}$

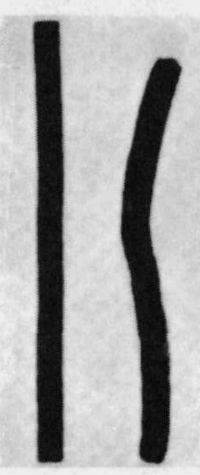

4 A 4 B

$2 \% \mathrm{Zr}-\mathrm{U}$

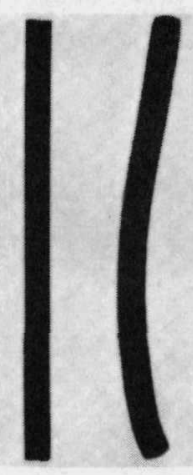

$5 \mathrm{~A} \quad 5 \mathrm{~B}$

$2 \% \mathrm{Zr}-\mathrm{U}$

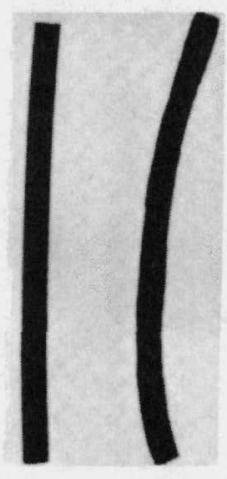

$6 \mathrm{~A} \quad 6 \mathrm{~B}$

$2 \% \mathrm{Zr}-\mathrm{U}$
$13-70$
$18-50$
$13-70$
UP TO 1200
$17-35$

WROUGHT \& HEAT TREAT .

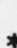
0.610 .80
$0.98 \quad 1.02$
1.70
0.89
$+0.10+0.01$
$+0.31-0.71$
$-0.32$
$-4.20$
$-0.48 \quad-3.96$

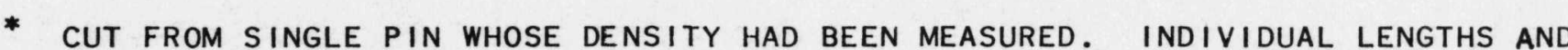
WEIGHTS NOT MEASURED PRIOR TO CYCLING.

** COUld nOt be measured accurately because of distortion

FIG. I

MOLYBDENUM-URANIUM AND ZIRCONIUM-URANIUM ALLOY PINS THERMALCYCLED IN NaK 
ALPHA CYCLED. 200 CYCLES FROM $150 \mathrm{~F}$ TO $1150 \mathrm{~F}$
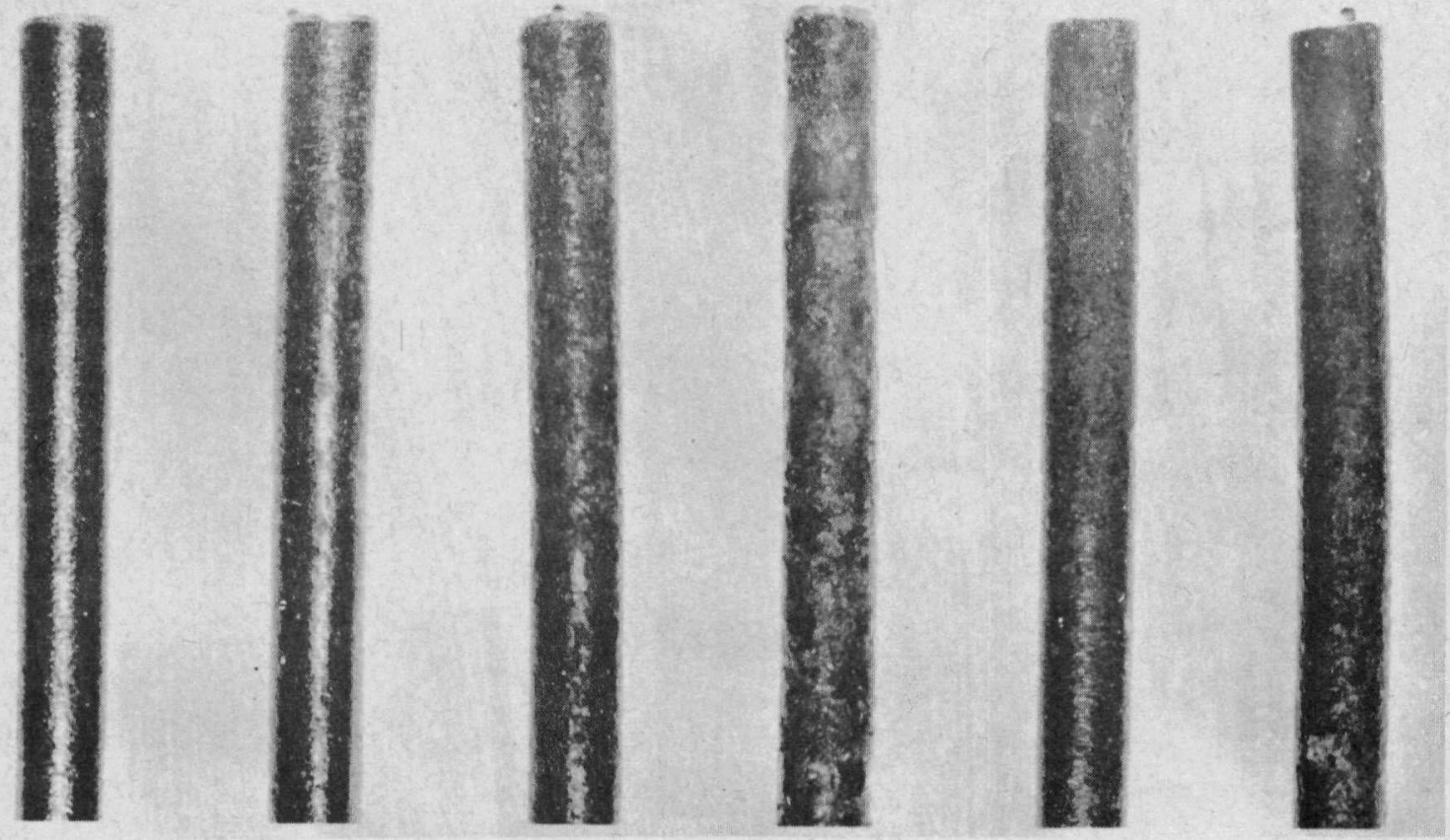

BETA CYCLED. 200 CYCLES FROM $200 \mathrm{~F}$ TO $1320 \mathrm{~F}$

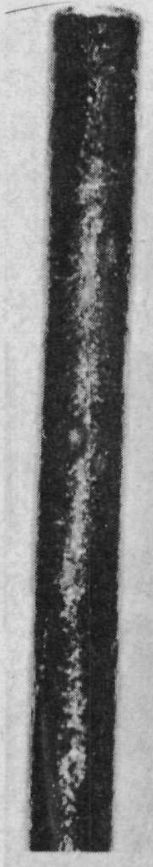

2.5\% $\mathrm{Mo}-\mathrm{U}$

$(18-50)$

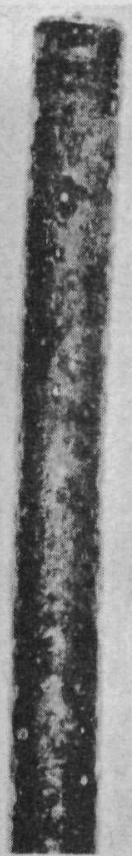

2\% Mo-U

$(13-70)$

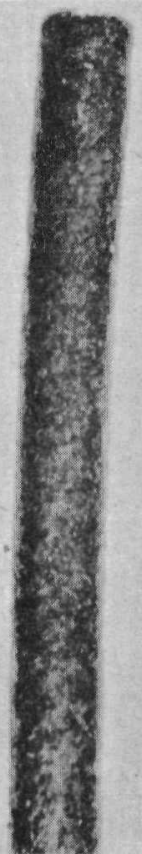

$1.4 \% \mathrm{Mo}-\mathrm{U}$

$(13-70)$

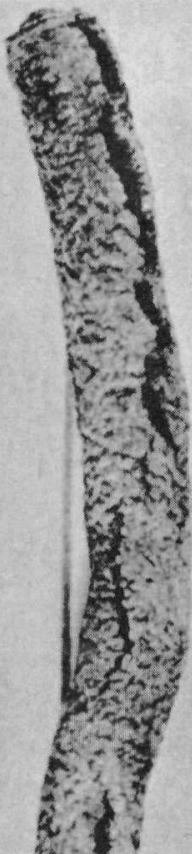

$2 \% \mathrm{Zr}-\mathrm{U}$

(UP TO 1200)

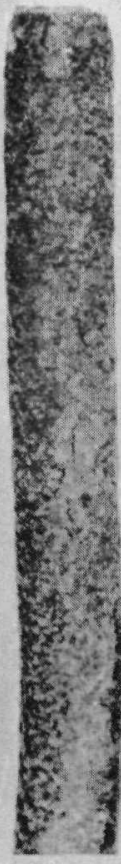

$2 \% \mathrm{Zr}-\mathrm{U}$

$(17-35)$

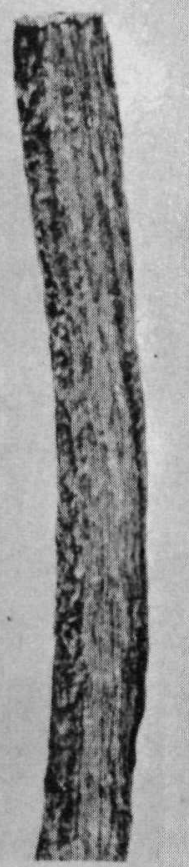

2\% $\mathrm{Zr}-\mathrm{U}$

WROUGHT \& HEAT TREAT

PARENTHESIZED NUMBERS INDICATE GRAIN SIZE IN MICRONS

FIG. 2

SURFACE CONDITION OF MOLYBDENUM-URANIUM AND ZIRCONIUM-URANIUM ALLOY PINS THERMALCYCLED IN NaK. MAGNIFICATION: $\mathrm{X}_{4}$

草 
$9 \%$ reduction before breakup. Further attempts at fabrication, including the use of heated rolls and extrusion, are in progress. Specimens for irradiation damage studies are also being prepared.

\section{Effects of Irradiation on Extruded U-Pu Alloys}

Ir radiation tests on a group of cast specimens containing 5, 10, and $15 \mathrm{w} / \mathrm{o} \mathrm{Pu}$ in $\mathrm{U}$ resulted in badly damaged specimens. The damage appeared to be chiefly the result of the large grain size of the specimens. In an effort to produce finer grained material, use has been made of the extrusion process. A total of 14 specimens was made by this means, using compositions of. 10, 15, and $20 \mathrm{w} / \mathrm{o} \mathrm{Pu}$ in U. They were irradiated in the MTR in NaK-filled capsules and have been examined for changes resulting from irradiation (see Table II).

The U-20\% Pu alloy in the as-extruded condition is quite promising in its behavior under irradiation. The material elongates at a relatively slow rate and maintains a smooth surface up to burnups of at least $0.60 \mathrm{a} / \mathrm{o}, 5100 \mathrm{MWD} / \mathrm{T}$.

\section{E. EBR-I}

The conversion ratio has been measured in the second $U$ fuel loading of EBR-I. It is a measure of the production of $\mathrm{Pu}^{239}$ from the natural $\mathrm{U}$ blanket per atom of $\mathrm{U}^{235}$ destroyed in the reactor. The ratio is determined by a knowledge of the relative amounts of fuel and blanket material and the measurement of the spatial neutron capture and fission distributions in $\mathrm{U}^{238}$ and $\mathrm{U}^{235}$, respectively, together with a determination of the effective $\alpha$ for $\mathrm{U}^{235}$ throughout the reactor.

The contributions of the various parts of the reactor to the conversion ratio are given in Table III. The conversion ratio for the second $\mathrm{U}$ loading of EBR-I with the cup about $\frac{1}{4}$ in. below its uppermost position was found to be $1.03 \pm 0.05$, based on the radiochemical normalization. The same conversion ratio was found using thermal capture and fission cross section normalization. This compares with the value of $1.01 \pm 0.05$ measured with the first loading.

The EBR-I was not in operation during the major part of this period. A number of special thermocouple rods including a special fuel rod were fabricated in preparation for a repetition of the oscillator experiment performed previously. It is hoped to obtain better temperature measurements than previously so as to get a better understanding of the role played by temperature variations in the oscillations. Instruments are also being assembled and checked.

The fabrication of fuel rod parts for the $\mathrm{Pu}$ loading is proceeding. 
Table II

EFFECTS OF IRRADIATION ON U-PU ALLOYS

\begin{tabular}{|c|c|c|c|c|c|c|c|}
\hline \multirow{2}{*}{$\begin{array}{l}\text { Nominal } \\
\mathrm{Pu}, \mathrm{w} / \mathrm{o}(\mathrm{a})\end{array}$} & \multirow[b]{2}{*}{ Condition } & \multicolumn{2}{|c|}{$\begin{array}{c}\mathrm{Co}^{60} \text {-Indicated } \\
\text { Burnup }\end{array}$} & \multirow{2}{*}{$\begin{array}{l}\text { Calculated } \\
\text { Central } \\
\text { Temp. , }{ }^{\circ} \mathrm{C}\end{array}$} & \multirow{2}{*}{$\begin{array}{l}\text { Length } \\
\text { Change, \% }\end{array}$} & \multirow{2}{*}{$\begin{array}{l}\text { Growth Rate, } \\
\text { microin./in/ } \\
\text { ppm burnup }\end{array}$} & \multirow[b]{2}{*}{ Remarks } \\
\hline & & $a / o$ & $\mathrm{MWD} / \mathrm{T}$ & & & & \\
\hline 0 & As extruded (b) & 0.045 & 380 & 85 & -4.1 & -91 & \\
\hline 0 & As extruded & 0.048 & 410 & 90 & -5.1 & -110 & \\
\hline 10 & As extruded & 0.70 & 6000 & 780 & - & - & $\begin{array}{l}\text { Part of specimen could } \\
\text { not be removed from } \\
\text { irradiation capsule }\end{array}$ \\
\hline 10 & As extruded & 0.35 & 3000 & 410 & - & - & $\begin{array}{l}\text { Could not be removed } \\
\text { from ir radiation } \\
\text { capsule }\end{array}$ \\
\hline 10 & Heat treated $(c)$ & 0.45 & 3800 & 520 & - & - & $\begin{array}{l}\text { Ignited \& burned before } \\
\text { measurements could be } \\
\text { taken }\end{array}$ \\
\hline 10 & Heat treated & 0.25 & 2100 & 300 & 1.5 & 6 & Very rough surface \\
\hline 15 & As extruded & 0.32 & 2700 & 380 & 47 & 150 & \\
\hline 15 & As extruded & 0.80 & 6800 & 890 & 97 & 85 & \\
\hline 15 & Heat treated & 0.70 & 6000 & 780 & 39 & 47 & Very rough surface \\
\hline 15 & Heat treated & 0.14 & 1200 & 190 & 49 & 285 & Very rough surface \\
\hline 20 & As extruded & 0.60 & 5100 & 680 & 5.2 & 9 & \\
\hline 20 & As extruded & 0.40 & 3400 & 460 & 5.7 & 14 & \\
\hline 20 & Heat treated & 0.52 & 4400 & 590 & 5.2 & 10 & Rough surface \\
\hline 20 & Heat treated & 0.25 & 2100 & 300 & 10 & 40 & Rough surface \\
\hline
\end{tabular}

(a) Balance natural U.

(b)Extrusion temperature 450 to $525^{\circ} \mathrm{C}$.

(c) All heat treatments consisted of heating to $645^{\circ} \mathrm{C}$, cooling to and holding at $500^{\circ} \mathrm{C}$ for one hour, and cooling to room temperature. 
Table III

CONVERSION RATIO MEASUREMENTS IN EBR-I*

\begin{tabular}{|c|c|c|c|c|}
\hline , & $\begin{array}{c}\text { Fast Fissions } \\
\text { Per Thermal } \\
\text { Column Fission } \\
\left(x \quad 10^{3}\right)\end{array}$ & $\%$ & $\begin{array}{c}\text { Fast Captures } \\
\text { Per Thermal } \\
\text { Column Capture } \\
\left(\times 10^{4}\right)\end{array}$ & $\%$ \\
\hline Outer Blanket & 6.86 & 5.1 & 1228 & 58.1 \\
\hline Inner Blanket & 2.26 & 1.7 & 570 & 27.0 \\
\hline Core & 123.8 & 92.5 & 115.7 & 5.5 \\
\hline Control Rods & 0.41 & 0.3 & 79.2 & 3.7 \\
\hline Lower Cup & 0.54 & 0.4 & 120.5 & 5.7 \\
\hline Total & 133.87 & 100.0 & 2113.4 & 100.0 \\
\hline
\end{tabular}

*Details of the measurements are presented in the Reactor Engineering Quarterly Report, ANL-5510.

F. ZPR-III

During the period from August 1, 1955, through October 31, 1955, all of the remaining aligning and testing of the ZPR-III machine and instrumentation was completed. Sufficient fuel and blanket material was delivered to do the first critical experiment.

The first assembly was built by starting with an assembly of solid depleted U (all drawers full, about $85 \%$ by volume) and building out radially, substituting full core drawers until criticality was reached. The final configuration was roughly cylindrical in shape. With all control rods in, the mass of $\mathrm{U}^{235}$ was $142.58 \mathrm{~kg}$, , and the reactor had a period of $44.5 \mathrm{sec}$. Correcting for this period, it is estimated that the critical mass of this first assembly with integral blanket was $141.5 \mathrm{~kg}$.

The composition of this first assembly was as follows:

Core area - fixed half $-1746 \mathrm{sq} \mathrm{cm}$

Moving half - $1777 \mathrm{sq} \mathrm{cm}$

Blanket was 9 in. thick at each end

Equivalent outer radius of the blanket -23 in. 


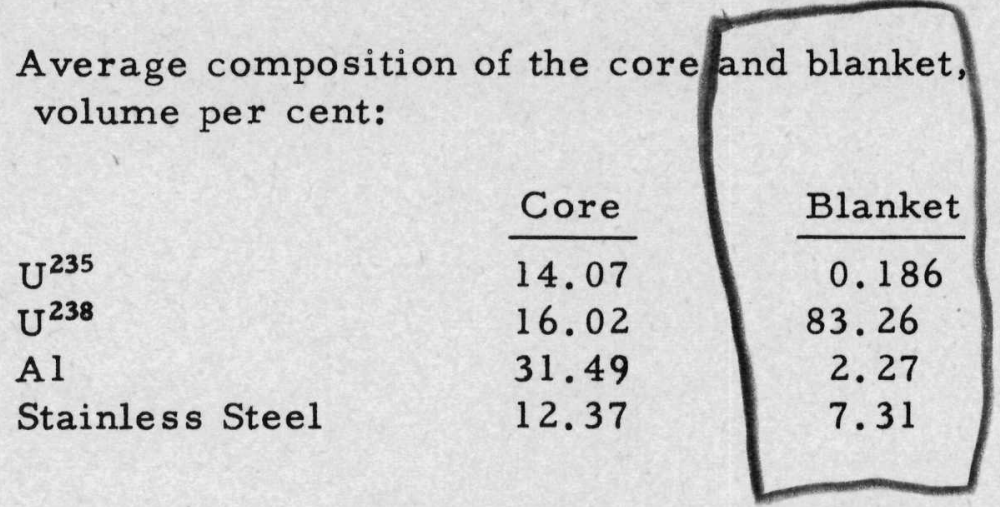

The next assembly was then built up of the same composition, but was rectangular in shape. With a rectangular array, $15.24 \times 17.88 \mathrm{x}$ $12.08 \mathrm{in}$. with a $9 \mathrm{in}$. end blanket, and the same radial blanket as the first as sembly, the critical mass was $142.4 \mathrm{~kg}$.

Various preliminary experiments were performed on the se assemblies, such as calibration of a control rod, worth of fuel at the core edge, worth of blanket material, and worth of a gap between the assembly halves.

"Fat Man" experiments were run in conjunction with the first loading. The "Fat Man" consisted of a slab of paraffin 48 by 48 by 8 in. With the table halves apart, this was driven between the halves adjacent to one face and multiplication measured after each increment of loading. These experiments demonstrated that the slab of paraffin gave less reactivity than the two halves assembled, but no conclusion on critical mass for this semithermal assembly could be gained from plotting the inverse multiplication curves. 
B. Metallurgical Development

1. Epsilonized U-3.8\% Si Alloy

a. Coextruded Rod

As a part of the program of testing material fabricated by Nuclear Metals, Inc., open-ended sections of two Zircaloy II-clad co-extruded $\mathrm{U}-3.8 \% \mathrm{Si}$ rods were tested at $290^{\circ} \mathrm{C}$ in degassed, distilled water. The alloy had been heated at $800^{\circ} \mathrm{C}$ for 7 days prior to extrusions. After about 10 days of testing, both core and bond appeared good. The corrosion rates were comparable with as-cast material. Additional samples will receive further epsilonizing treatment to determine if the corrosion rate can be lowered.

\section{b. Effect of Irradiation}

One $10 \%$ enriched U-3.8\% Si sample cast at Argonne and epsilonized at $825^{\circ} \mathrm{C}$ for two hours was tested bare after an indicated $\mathrm{U}$ burnup of $0.71 \mathrm{a} / \mathrm{o}$. Results of corrosion tests at 260 and $290^{\circ} \mathrm{C}$ are listed in Table IV. Although corrosion behavior was only fair, it was approximately the same as shown by the alloy before irradiation. It appears that irradiation is not harmful to the corrosion resistance of this alloy.

Two specimens of U-3.8\% Si alloy cast by Nuclear Metals, Inc., and scheduled for post-irradiation corrosion testing, were irradiated to $U$ atom burnups of 0.12 and $0.33 \%$. The specimens changed in length 2.1 and $-1.4 \%$, respectively, and some surface cracks developed in the specimen having the higher burnup. The specimens were epsilonized at $800^{\circ} \mathrm{C}$ for $2-3 / 4$ days prior to irradiation. The appearance of the specimens before and after irradiation is shown in Fig. 3. The effects of irradiation on the two specimens were generally the same as noted on an earlier group which was irradiated at higher temperatures and to higher burnups. 
Table IV

\section{CORROSION OF IRRADIATED U $-3.8 \%$ Si ALLOY}

$\begin{array}{cccc}\begin{array}{c}\text { Test Temp., } \\ { }^{\circ} \mathrm{C}\end{array} & \begin{array}{c}\text { Time, } \\ \text { hr }\end{array} & \begin{array}{c}\text { Corrosion } \\ \text { Rate, mcd* }\end{array} & \end{array}$

* Pre-irradiation corrosion rate at $290^{\circ} \mathrm{C}$ was $15.7 \mathrm{mcd}$ after $88 \mathrm{hr}$. * Based on major piece.

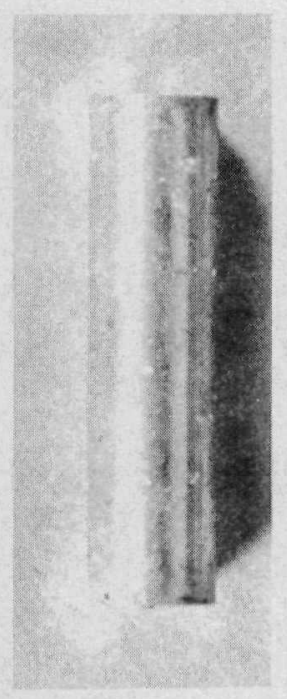

No Irradiation

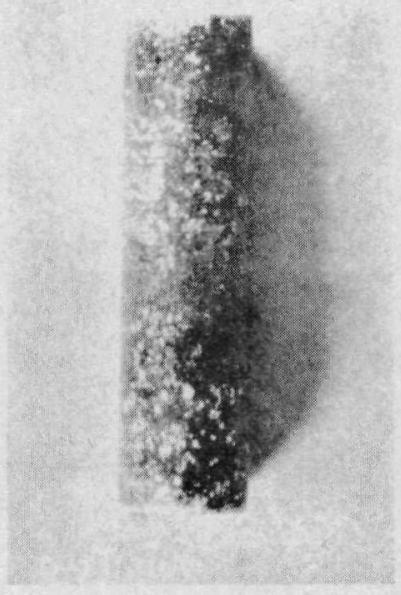

$0.12 \%$ Burnup Calculated Surface

Temp. $150^{\circ} \mathrm{C}$

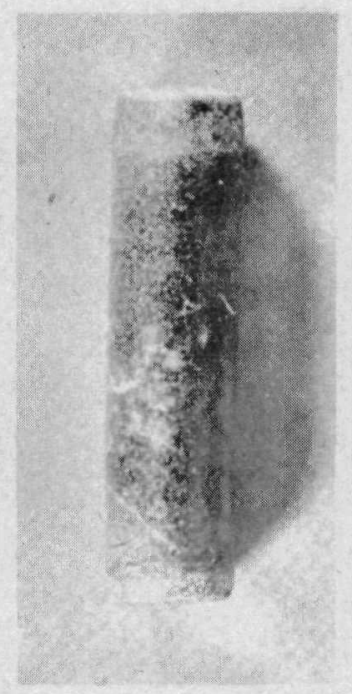

$0.33 \%$ Burnup Calculated Surface

Temp. $310^{\circ} \mathrm{C}$

Fig. 3

U-3.8\% Si Alloy Epsilonized at $800^{\circ} \mathrm{C}$ (All Samples: $2 \mathrm{X}$ ) 


\section{2. $3 \mathrm{w} / \mathrm{o} \mathrm{Nb}-0.48 \mathrm{w} / \mathrm{o} \mathrm{Sn}$ Alloy \\ Effect of Irradiation}

Two 10\% enriched samples cast at Argonne were tested in degassed, distilled water at $260^{\circ} \mathrm{C}$ for $70 \mathrm{hr}$. The samples were water quenched after $4 \mathrm{~min}$ at $800^{\circ} \mathrm{C}$ and aged at $350^{\circ} \mathrm{C}$ for $6 \mathrm{hr}$. Indicated $\mathrm{U}$ burnups were $0.58 \mathrm{a} / 0$ and $0.19 \mathrm{a} / \mathrm{o}$, respectively. Pre-irradiation corrosion rates at $290^{\circ} \mathrm{C}$ were $28.3 \mathrm{mg} / \mathrm{cm}^{2} /$ day (mcd) and $31.3 \mathrm{mcd}$, respectively, for $88 \mathrm{hr}$ tests.

After irradiation the samples were roughened and warped. Growth rates were 15 and $38 \mu \mathrm{in} . / \mathrm{in} . / \mathrm{ppm}$ burnup, respectively. The samples were completely disintegrated in the corrosion test.

\section{Effects of Irradiation on U-Powder Compacts}

Irradiations are being made on three types of hot-pressed $\mathrm{U}$-powder compacts, prepared by Sylvania Electric Products, Inc. These samples are $3 / 8$ in. diam and 1 in. long. The following types of compacts are being investigated: (1) solid, full density material; (2) full density material with 1/16-in. diam axial core hole; (3) partial density material with approximately $12.5 \%$ porosity.

Groups were irradiated at various temperatures in the MTR to burnups ranging up to $0.53 \%(4500 \mathrm{MWD} / \mathrm{T})$. The observed results of this irradiation are summarized in Table V. Photographs of typical specimens are shown in Fig. 4.

The full density material, both with and without core hole, shortened under irradiation. These compacts were formed by end pressing. On the other hand, the partial density compacts, which were formed by side pressing, lengthened under irradiation and developed elliptical cross sections. These results indicate that a slightly preferred orientation is present in the texture of the compacted specimens.

\section{Properties of Urania-Thoria Bodies}

Additional $\mathrm{U}_{3} \mathrm{O}_{8}-\mathrm{ThO}_{2}$ mixtures containing from $60 \mathrm{w} / 0 \mathrm{U}_{3} \mathrm{O}_{8}$ to $90 \mathrm{w} / 0 \mathrm{U}_{3} \mathrm{O}_{8}$ were fabricated by iso-static pressing under a pressure of $50,000 \mathrm{psi}$. These bodies were fired in air to temperatures of 1650,1750 , and $1850^{\circ} \mathrm{C}$ for various time cycles in an effort to eliminate the cracking which had been encountered in bodies of these compositions. All of these bodies disintegrated in firing. As an aid to stabilize a high $\mathrm{U}_{3} \mathrm{O}_{8}$ body, several oxides $\left(\mathrm{MgO}, \mathrm{CaO}, \mathrm{CaF}_{2}, \mathrm{Al}_{2} \mathrm{O}_{3}\right.$ and $\mathrm{ZrO}_{2}$ ) were added in amounts of 
Table V

EFFECTS OF IRRADIATION ON HOT PRESSED U POWDER COMPACTS

\begin{tabular}{|c|c|c|c|c|}
\hline Specimen Type & $\begin{array}{c}\mathrm{Co}^{60} \text {-Indicated } \\
\text { Burnup, a } / \mathrm{o}\end{array}$ & $\begin{array}{l}\text { Irradiation } \\
\text { Temp. Range }\end{array}$ & $\begin{array}{l}\text { Growth Rate, } \\
\text { microin./in./ } \\
\text { ppm Burnup }\end{array}$ & Remarks \\
\hline Solid & 0.49 & $\alpha+\beta$ & - & $\begin{array}{l}\text { Could not be removed } \\
\text { from irradiation } \\
\text { capsule. }\end{array}$ \\
\hline Solid & 0.52 & $\alpha+\beta$ & - & Same \\
\hline Solid & 0.45 & $\alpha$ & -7 & Uneven diameter change \\
\hline Cored & 0.53 & $\alpha+\beta$ & -50 & Badly distorted \\
\hline Cored & 0.16 & $\alpha$ & -25 & Defect at one end \\
\hline Cored & 0.46 & $\alpha+\beta$ & -26 & Warped \\
\hline $13.0 \%$ porosity & 0.51 & $\alpha+\beta$ & 39 & Oval-shaped cross section \\
\hline $12.5 \%$ porosity & 0.33 & & 53 & Same \\
\hline
\end{tabular}


Full density compacts with $1 / 16$ in. axial hole. The specimen with $0.53 \mathrm{a} / \mathrm{o}$ burnup ignited and burned to oxide spontaneously shortly after it was photographed.

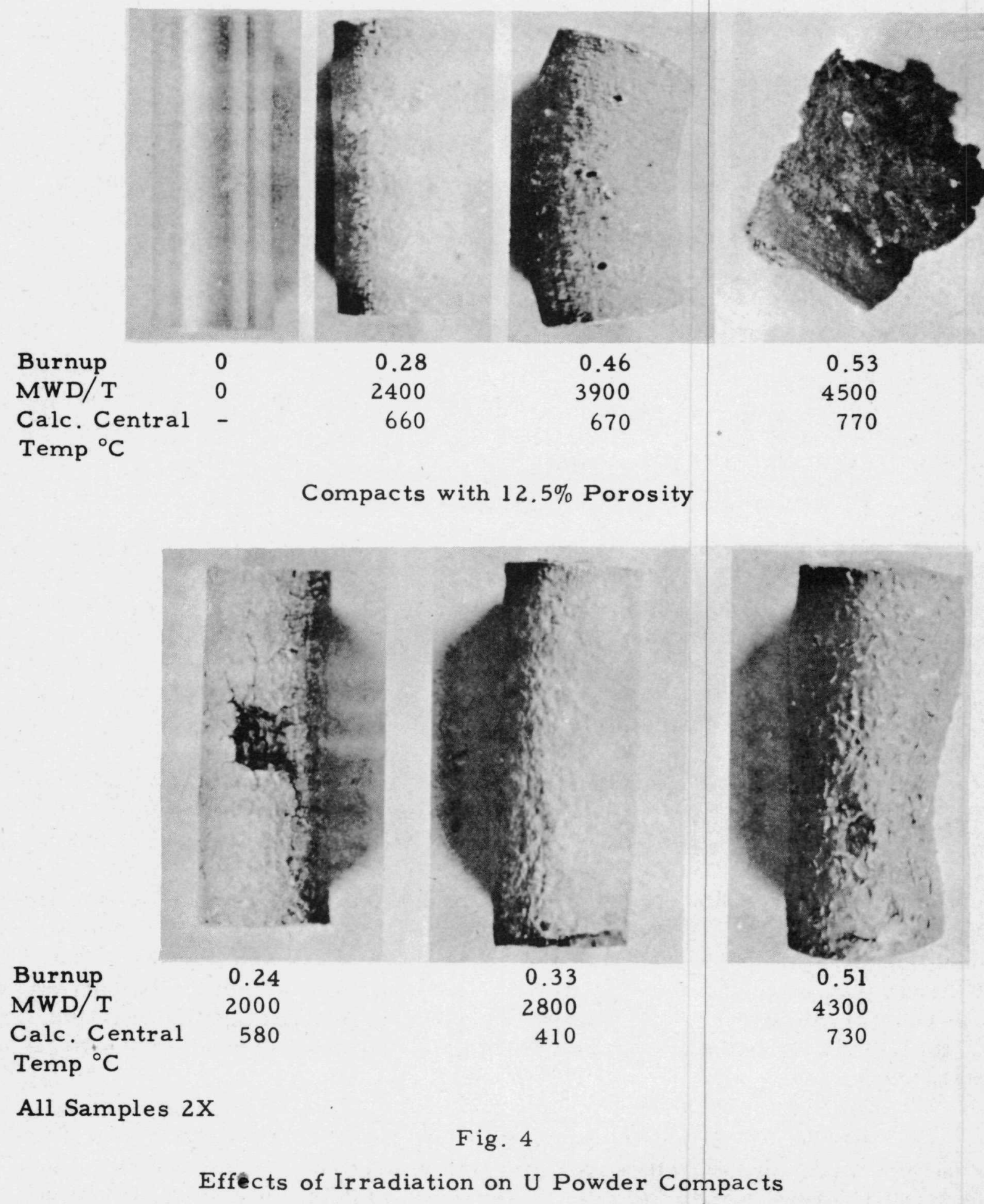


$2.5 \mathrm{w} / \mathrm{o}$. These compositions when fabricated were fired to $1750^{\circ} \mathrm{C}$ in air. The body containing $\mathrm{Al}_{2} \mathrm{O}_{3}$ appeared to be sound, and the body containing $\mathrm{MgO}$ appeared to be good, but showed a few minor cracks which could be due to faulty pressing. The other bodies were cracked rather severly.

\section{Effects of Irradiation on $\mathrm{UO}_{2}$ Specimens}

Two pressed and sintered 3/16-in. diam specimens of $\mathrm{UO}_{2}$ were irradiated to $0.048 \mathrm{a} / \mathrm{O} \mathrm{U}$ burnup in a NaK-filled capsule in the MTR. It was found on examining the specimens after irradiation that they had fractured into a number of small pieces. The possibility of damage because of mechanical shock could not be ruled out, however, because the specimens were free to move about in their capsules.

Accordingly, two identical specimens were irradiated after packing in steel wool to eliminate the possibility of mechanical damage. Irradiation conditions were as follows:

$\begin{array}{lcc}\text { U atom burnup, } \% & 0.16 & 0.38 \\ \text { Calculated central temp., }{ }^{\circ} \mathrm{C} & 190 & 315 \\ \text { Calculated surface temp., }{ }^{\circ} \mathrm{C} & 95 & 140 \\ \text { Diameter change, } \% & 0.0 & 0.08\end{array}$

Both specimens broke into three pieces during irradiation.

6. High Temperature Corrosion Resistant Alloys

\section{a. Static Tests}

An attempt was made to improve the aqueous corrosion resistance of $2 \mathrm{~S} \mathrm{Al-1 \%} \mathrm{Ni} \mathrm{alloy} \mathrm{by} \mathrm{further} \mathrm{alloying.} \mathrm{It} \mathrm{had} \mathrm{been} \mathrm{found} \mathrm{that}$ the weight gain curves for $1 / 2,1,1 \frac{1}{2}$, and $2 \% \mathrm{Ni}$ in $2 \mathrm{~S} \mathrm{Al} \mathrm{when} \mathrm{corroded} \mathrm{in}$ $315^{\circ} \mathrm{C}$ distilled water had the same slope, i.e., corrosion rate, within the experimental error. This suggested that the cathodic corrosion reaction (liberation of $\mathrm{H}_{2}$ ) was not the rate-controlling step in the corrosion, since changing the amount of cathodic area by a factor of the order of 4 did not influence the corrosion rate. However, this argument is not clean-cut, since it is possible that the rate is controlled in the anodic part of the reaction, but the ability of the anodes to control might still be a function of the $\mathrm{H}_{2}$ liberated.

Attention was focused on the anodic reaction, namely, oxidation of $\mathrm{Al}$. In the field of gaseous oxidation it is well established that the oxidation rate of many metals is sensitive to relatively small additions 
of certain other alloying metals. The alloying metals are usually of different ionic charge but of equivalent ionic size to the base metal. It is considered that these metal ions substitute for the base metal ion in the ionic structure of the oxide, modifying its diffusion characteristics.

Tables of ionic size and ionic charge were used to select the alloying additions for Al. About $0.1 \mathrm{a} / \mathrm{o}$ was the intended amount to be added to a base of $\mathrm{Al}-0.9 \% \mathrm{Ni}$. The results are shown in Table VI. Silicon analyses (pickup from the crucible) are also shown since previous work has indicated the need for low $\mathrm{Si}$ content. The figures shown in the column on static corrosion behavior were obtained by testing samples for 3 days and 2 weeks. The difference in metal loss/decimeter ${ }^{2}$ divided by the time for these two samples was the corrosion rate for this 11-day period. The 3-day time was chosen because a large part of the initial rapid corrosion is over by this time. It is obvious that this test was unfair to the Be since the inadvertent Si pickup turned out to be nine times the amount of Be addition. High purity alundum crucibles have been ordered to reduce the Si pickup.

Table VI

EFFECT OF ALLOYING ADDITIONS ON THE CORROSION OF AN Al-0.9\% Ni ALLOY

Analyzed

Concentration

of Additive,

Additive $\frac{w / 0}{0.009 \mathrm{Si}-.004 \mathrm{Fe}}$

Corrosion Behavior

(Rate in mdd for period 3-14 days)

None

$2.4 \mathrm{mdd}$

(Surface blistering at 14 days)

$\mathrm{Be}$

$0.01 \mathrm{Be}-0.09 \mathrm{Si}$

Disintegrated

$\mathrm{Mg}$

$0.74 \mathrm{Mg}-0.03 \mathrm{Si}$

Disintegrated

Cr

$0.20 \mathrm{Cr}-0.09 \mathrm{Si}$

$\mathrm{Fe}$

$0.19 \mathrm{Fe}-0.05 \mathrm{Si}$

Ti

$0.15 \mathrm{Ti}-0.07 \mathrm{Si}$

B

0.03 B $-0.01 \mathrm{Si}$

Disintegrated

2.3

1.6

Disintegrated 
Tests are now in progress to evaluate $\mathrm{Ti}$ as an additive. Mixed additions of $\mathrm{Fe}$ and $\mathrm{Ti}$ are ineffectual in reducing the corrosion rate of the $\mathrm{Al}-\mathrm{Ni}$ alloy.

\section{b. Dynamic Tests}

Approximately 120 specimens of $\mathrm{Al}-\mathrm{Ni}$ alloy $\mathrm{M}-388$ and $\mathrm{Al}-\mathrm{Cu}$ alloy $\mathrm{X}-2219$ have been tested under varying conditions of $\mathrm{pH}$, velocity, $\mathrm{H}_{2}$ gas, and temperature. The total test time is 8 weeks with loop shutdown and specimen withdrawal every two weeks. In general, the Al-Ni material is better than Al-Cu from viewpoints of total corrosion and uniformity of corrosion in comparative testing of only 4 weeks. $\mathrm{Al}-\mathrm{Cu}$ is prone to pitting attack, and its scale is more easily damaged by mechanical and thermal shock.

Test results on $\mathrm{Al}$ alloys have been somewhat confusing because of a consistent difference in corrosion of originally loaded samples and replacement samples. In all cases of normal loop operation replacement samples show more corrosion. This phenomenon is being investigated and is currently believed to be due to the difference in $\mathrm{H}_{2}$ gas content of the water in contact with originally loaded and replacement samples.

It should be noted that $90 \%$ of the Al-Ni alloy $\mathrm{M}-388$ samples as received for test contained inclusions of dirt and foreign matter at the surface, and it is questionable whether these inclusions extend throughout the metal. Results of individual tests follow.

Loop No. $1,260^{\circ} \mathrm{C}, \mathrm{pH} 5.0$ - Original Samples: This loop, maintained at pH 5.0 by means of a cation resin bed regenerated with $\mathrm{H}_{2} \mathrm{SO}_{4}$, has completed the 8 -week total test period for Al-Ni M-388 alloy. The corrosion rates were as follows:

$\begin{array}{ccc}\text { Water Velocity, fps } & & \text { Penetration Rate, mils/yr } \\ & & 2.5 \\ 7 & 1.4 \\ \text { Semi-Static } & & 1.2\end{array}$

In all cases the samples corroded uniformly with no pitting or erosion-corrosion areas. Figure 5 shows the appearance of one of the Al-Ni samples at the end of two weeks of corrosion test. This sample was the only one which had any white oxide.

Loop No. $3,260^{\circ} \mathrm{C}, \mathrm{pH} 6.5$ - Originally Loaded Samples: This loop, with the water continuously bypassed through a mixed bed demineralizer, has completed 6 weeks of the scheduled 8 -week test period on Al-Ni alloy (see Fig. 6). The approximate corrosion rates were: 
Fig. 5

Dynamic Corrosion Test of Al-1\% Ni Alloy, $1074 \mathrm{hr}$ at $260^{\circ} \mathrm{C}$, $21 \mathrm{ft} / \mathrm{sec}, \mathrm{pH} 5.0$ (Sample: 2 in. by 2 in.) 


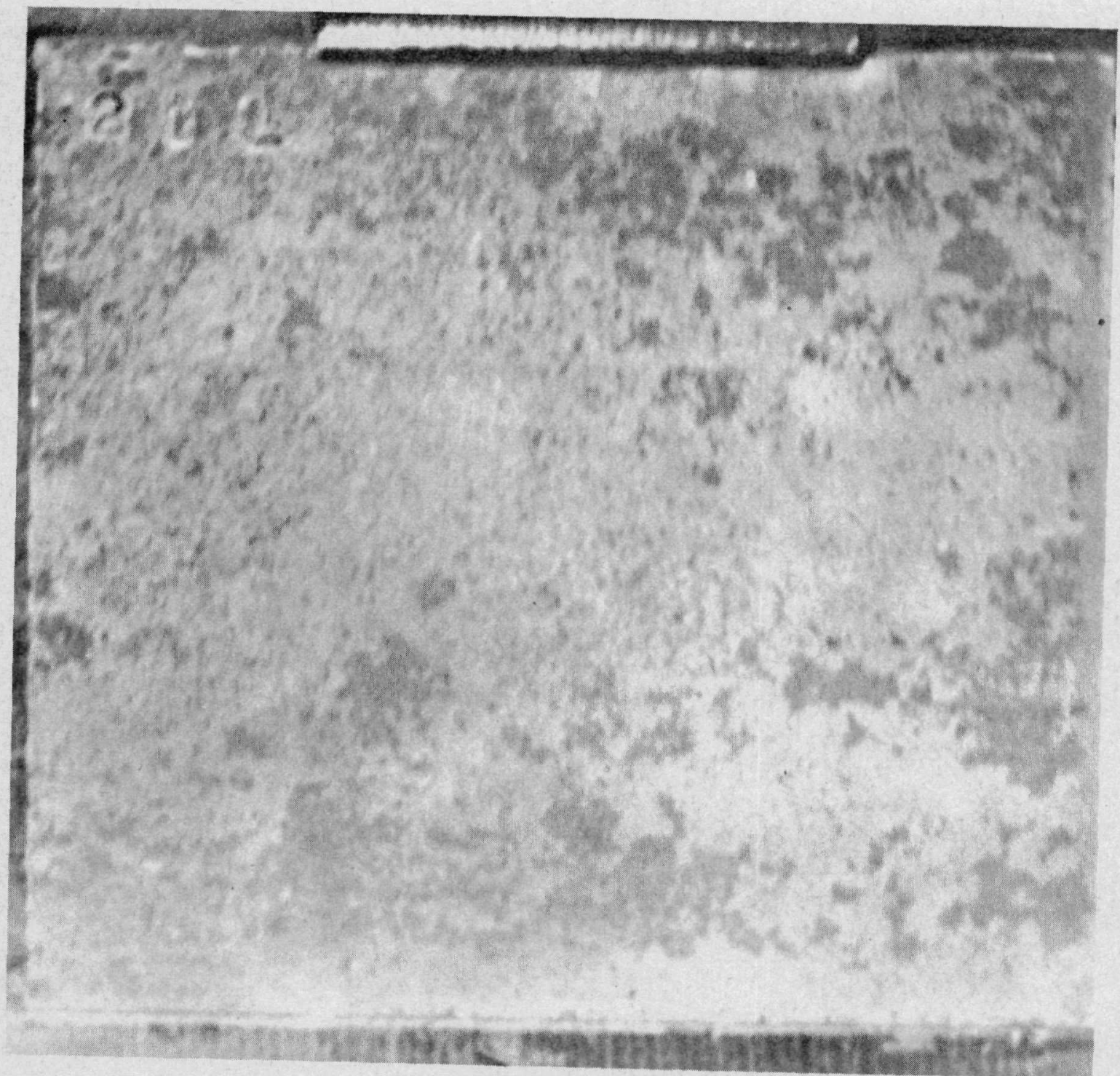

Fig. 6

Dynamic Corrosion Test of Al-1\% Ni Alloy, $1058 \mathrm{hr}$ at $260^{\circ} \mathrm{C}$, $16 \mathrm{ft} / \mathrm{sec}, \mathrm{pH} 6.5-7.0$ (Sample: 2 in. by 2 in.) 


$\begin{array}{cc}\frac{\text { Water Velocity, fps }}{16} & \text { Penetration Rate, mil/yr } \\ & 2.8 \\ \text { Semi-Static } & 2.0 \\ & 2.0\end{array}$

Examination of the 16-fps samples showed erosioncorrosion areas at leading edges and around the holding combs. The $6 \mathrm{fps}$ and static samples showed uniform corrosion.

\section{c. Replacement Samples of Al-Ni Alloy}

Samples used in dynamic loops as replacements to hold the area configuration have shown considerably higher corrosion (at least as concerns intercept) than originally loaded samples. The problem first arose in the boric acid loop and was attributed at that time to a varying $\mathrm{pH}$. The difference in corrosion is considerable and may vary by as much as a factor of 4 . The higher the velocity the more pronounced the acceleration of replacement sample corrosion.

The accelerated corrosion of replacement dynamic stream samples continued to some degree in Loop No. 1 (pH 5) and Loop No. 3 ( $\mathrm{pH}$ 6.5). There appears to be a connection between increased replacement sample corrosion and the $\mathrm{H}_{2}$ gas content of the flowing loop. Data at present show that $\mathrm{Al}-\mathrm{Ni}$ corrosion has been less in the presence of higher $\mathrm{H}_{2}$ content, and this could account for the replacement sample corrosion problem, since the $\mathrm{H}_{2}$ content of the loops is highest in the initial two-week periods. A test has been started to investigate the effect of $\mathrm{H}_{2}$ as an inhibitor in $\mathrm{Al}-\mathrm{Ni}$ corrosion.

\section{d. Al-Cu Alloy X-2219}

Al-Cu alloy $\mathrm{X}-2219$ shows a greater stripped weight loss than Al-Ni under the same water conditions. The alloy shows small surface pits and localized erosion-corrosion attack in 16 -fps, $\mathrm{pH} 6.5$ water. It is more sensitive to velocity than $\mathrm{Al}-\mathrm{Ni}$. The stripped weight loss at the end of 4 weeks at $\mathrm{pH} 5.0$ for $\mathrm{Al}-\mathrm{Cu}$ was $6.70 \mathrm{mg} / \mathrm{cm}^{2}$ at $21 \mathrm{fps}$, and $3.75 \mathrm{mg} / \mathrm{cm}^{2}$ at $7 \mathrm{fps}$.

$\mathrm{Al}-\mathrm{Cu}$, like $\mathrm{Al}-\mathrm{Ni}$, does not show erosion-corrosion attack in high-velocity water at $\mathrm{pH} 5.0$; however, surface pitting of $\mathrm{Al}-\mathrm{Cu}$ still occurs at this reduced $\mathrm{pH}$.

e. Stainless Steel Corrosion at $260^{\circ} \mathrm{C}$ and $\mathrm{pH} 5.0$ and 6.5

Austenitic stainless steel samples were corrosion tested along with the $\mathrm{Al}$ alloy samples in the higher $\mathrm{pH}$ water. It appears that stainless steel gains weight in $\mathrm{pH} 6.5$ water and loses weight in 
pH 5.0 water, with about equal weight change rates. Rates are somewhat confused by a varying amount of $\mathrm{H}_{2}$ gas from period to period. The weight change rate in pH 5.0 water is approximately $0.05 \mathrm{mg} /\left(\mathrm{cm}^{2}\right)(\mathrm{mo})$ which is in close agreement with the normal rate.

\section{f. Crevice Corrosion Between Al-Ni and Stainless Steel}

Autoclave work had indicated that $\mathrm{Al}-\mathrm{Ni}$ specimens when coupled to stainless steel type 304 washers tended to seize together and required force to separate the pieces. An autoclave experiment was run at $212^{\circ} \mathrm{C}$ to evaluate the problem of sticking the fuel element end box cones into a bottom support plate of stainless steel type 304. Three miniature cones were tested and withdrawn at the end of 7,33 , and 44 days, respectively. In no case was any force required for withdrawal. The unit loading pressure of the cone during corrosion was 3 psi. The Al-Ni cones showed evidence of crevice corrosion pitting, and this occurred consistently when $\mathrm{Al}-\mathrm{Ni}$ was coupled to stainless steel in a static system. It has never been observed in a dynamic system.

\section{g. Examination of Ni-Treated Al Plates From Corrosion Test in the MTR Loop}

A microexamination of the $6 \mathrm{Ni}$-treated $\mathrm{Al}$ corrosion test plates after irradiation in the MTR was made. Two each of $2 \mathrm{~S} \mathrm{Al}$ plates had been prepared by Kanegin $\mathrm{Ni}$ plating and by $\mathrm{Ni}$ electroplating, and two plates were specially prepared alloys of $2 \mathrm{~S} \mathrm{Al-0.46 \%} \mathrm{Ni}$. They were tested in $260^{\circ} \mathrm{C}$ water for $530 \mathrm{hr}$ and had additional periods of $50 \mathrm{hr}$ at $230^{\circ} \mathrm{C}$ and $150 \mathrm{hr}$ at $175^{\circ} \mathrm{C}$. The total integrated flux was $5 \times 10^{20} \mathrm{nvt}$.

The examination showed that much of the Kanegin and electroplated $\mathrm{Ni}$ had been corroded and flaked away, exposing the under - * lying Al to corrosive attack. Corrosion of the $\mathrm{Ni}$ alloy, however, did not appear to be as severe as the corrosion of the Al plates exposed after failure of the $\mathrm{Ni}$ coatings.

\section{Inspection of $800^{\circ} \mathrm{C} \mathrm{Na}$ Loop Welds}

Metallographic examination of weld samples cut from type 347 stainless steel piping of a recirculating $800^{\circ} \mathrm{C} \mathrm{Na}$ loop reveal typical spheroidization of ferrite and carbides with limited sigma phase formation (see Fig. 7). Although the sigma phase forms fastest at temperatures between 730 and $815^{\circ} \mathrm{C}$, general weld embrittlement was not serious since the loop operated at temperature only $160 \mathrm{hr}$. However, extensive cracking in a field weld which lacked proper weld preparation was evident.

The nature of these cracks, root cracking, heat affected zone cracking (Fig. 8), and cracking along grain boundary carbides (Fig. 9), emphasize the need for strict observance of the welding procedures 


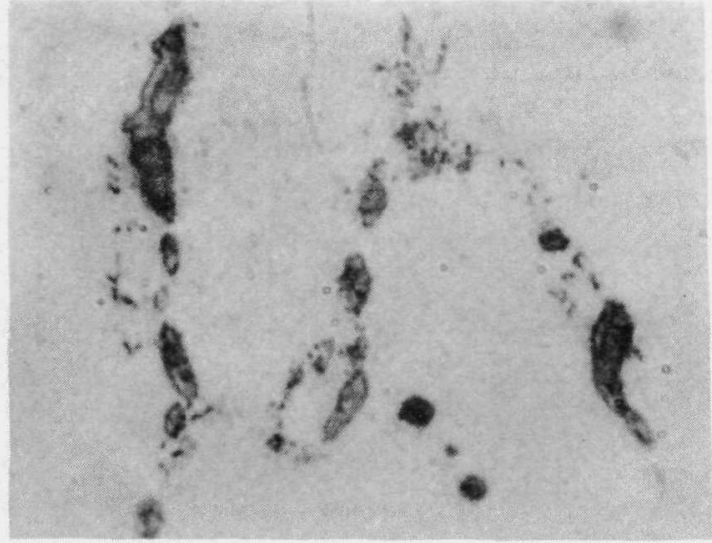

FIG. 7

SPHEROIDIZED CARBIDE AND SIGMA PHASE FORMATION

AUSTENITE: LIGHT BACKGROUND, CARBIDE: DARK STAIN. SIGMA: LIGHT BORDERED AREAS ADJACENT TO CARBIDES.

ETCH: 10 NORMAL KOH. STAIN: $\mathrm{HNO}_{3}$

$(\sim 2000)$

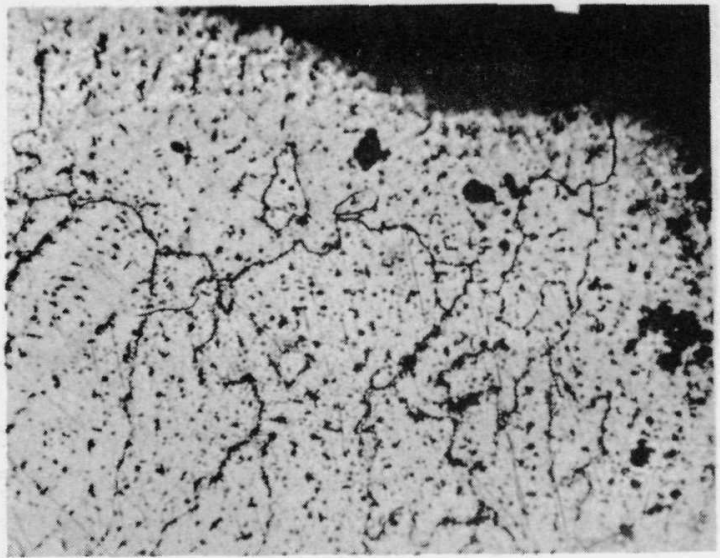

FIG. 9

CRACKING ALONG CARBIDES AT GRAIN BOUNDARIES

ETCH: OXALIC ACID

$(\sim 200)$

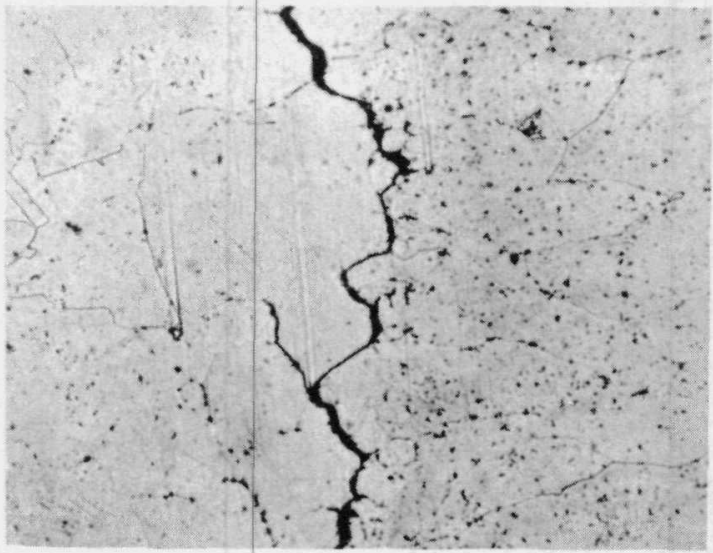

FIG. 8

HEAT-AFFECTED ZONE CRACK

ETCH: OXALIC ACID

$(\sim 200)$

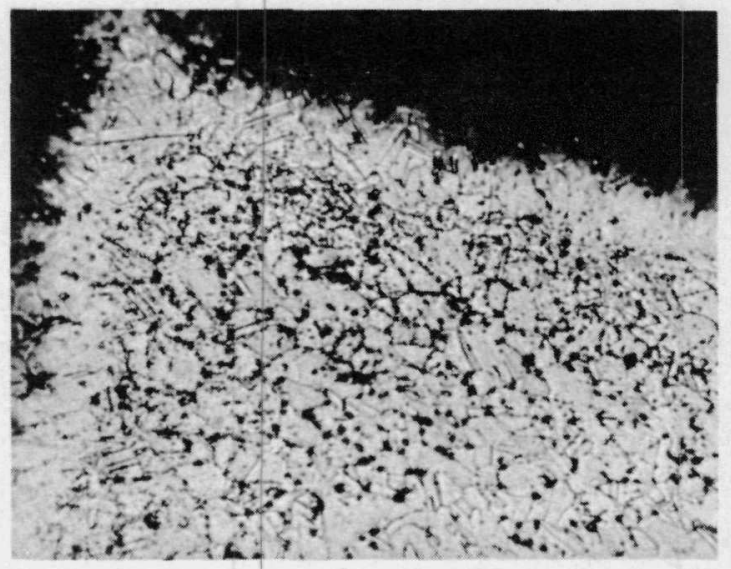

FIG. 10

DECARBURIZATION OF SODIUM-WETTED SURFACE

ETCH: HCI -ETHYL ALCOHOL

( 300) 
currently used in fabricating $\mathrm{Na}$ loops. The welding procedure minimizes root cracking by making the first pass with an inert arc weld rod. Some control of heat-affected zone cracking is possible by using small-size grain boundaries where carbide and sigma formation occurs is delayed by using low-ferrite, extra low-carbon weld rod. Decarburization of the surface is shown in Fig. 10.

Table VII compares recommended weld metal composition with the chemical analysis of the cracked field weld described above.

Table VII

CHEMICAL COMPOSITION OF DEPOSITED WELD METAL, $\%$

\begin{tabular}{lcc} 
& Recommended* & Cracked Weld \\
\cline { 2 - 3 } $\mathrm{C}$ & $0.07-.0 .10$ & 0.24 \\
$\mathrm{Mn}$ & $1.50-2.50$ & 1.11 \\
$\mathrm{Si}$ & 0.50 & 0.63 \\
$\mathrm{Cr}$ & $18.4-20.5$ & 20.40 \\
$\mathrm{Ni}$ & $9.0-10.5$ & 10.96 \\
$\mathrm{Nb}$ & $0.60-0.90$ & 0.66 \\
$\mathrm{Mo}$ & - & 0.13 \\
$\mathrm{Si}$ C ratio, & $5 / 1$ & $2.6 / 1$ \\
$\quad$ max. & &
\end{tabular}

* Specification Limits for Special Low-Ferrite, Type 347 Welding Electrodes

C. Development of Shielding and Control Rod Materials

Small quantities of AISI type 302 stainless steel containing B or mixed rare earth oxides have been produced by hot direct extrusion of powder mixtures. High purity metallic B powder was used as the B source in the stainless steel-boron materials. Lindsay \#920,1 a mixture containing approximately $50 \mathrm{w} / 0 \mathrm{Sm}_{2} \mathrm{O}_{3}, 25 \mathrm{w} / 0 \mathrm{Gd}_{2} \mathrm{O}_{3}$, plus other rare earth oxides, was used in the stainless steel-rare earth series.

Alloys containing 3 and $10 \mathrm{w} / \mathrm{o}$ of either $\mathrm{B}$ or mixed rare earth oxides in type 302 stainless steel were attempted. Extrusions of approximately full theoretical density were obtained with all compositions except those containing $10 \mathrm{w} / \mathrm{O} \mathrm{B}$, which were extremely hot short, and broke up upon leaving the die during extrusion.

${ }^{1}$ Lindsay Light \& Chemical Co., West Chicago, Illinois 
Sections of $3 \mathrm{w} / \mathrm{O} \mathrm{B}$, and 3 and $10 \mathrm{w} / \mathrm{o}$ mixed rare earth oxide extrusions were examined metallographically. The $B$ or oxide additions were observed to be fairly uniformly distributed throughout the stainless steel matrix in all cases. Chemical analyses to corroborate the metallographic observations have not as yet been made.

Extensive high temperature distilled water corrosion testing of the subject materials has not been done, but a few exploratory tests of as-extruded sections of $3 \mathrm{w} / \mathrm{O} B$ and 3 and $10 \mathrm{w} / \mathrm{o}$ rare earth oxide in distilled water at $350^{\circ} \mathrm{C}$ for periods of up to $120 \mathrm{hr}$ have indicated that they have promising resistance to corrosion.

\section{Remote Control Development}

1. Electric Discharge Machine, Model 1.

A test machine to study the feasibility of electric discharge cutting of radioactive material has been used to cut approximately 30 highly radioactive $\mathrm{U}$ alloy fuel pins. Cutting was done under distilled water because of the ease of disposal of the solution. The contamination of the machine was very low, and negligible contamination of the cave resulted from the cutting operation. Good contamination control was achieved as a result of the submerged cutting and by locally hooding and ventilating the apparatus.

2. Optical Glass Study

Microscope objectives have been prepared from radiationprotected optical glasses. Measurements have been completed on $5 \mathrm{X}, 20 \mathrm{X}$, and $40 \mathrm{X}$ protected lenses in the exposure range of $10^{6}$ to $10^{8} \mathrm{r}$ using a $\mathrm{Co}^{60}$ source. Comparative measurements were made on standard $5 \mathrm{X}$ and $40 \mathrm{X}$ lenses in the exposure range of $10^{5}$ to $10^{7} \mathrm{r}$. Protected lenses are good for a continuous exposure considerably greater than $10^{8} \mathrm{r}$. Total exposure is probably limited by damage to the lens cement. The attenuation of the green line of $\mathrm{Hg}$ is increased by a factor of 1.1 for the $5 \mathrm{X}, 1.2$ for the $20 \mathrm{X}$, and 2.0 for the $40 \mathrm{X}$ lens after an exposure of $10^{8} \mathrm{r}$ at an intensity of $10^{6} \mathrm{r} / \mathrm{hr}$. By comparison, the standard $5 \mathrm{X}$ lens has an attenuation factor of 3.2 after an exposure of $10^{7} \mathrm{r}$ at an intensity of $10^{5} \mathrm{r} / \mathrm{hr}$. A standard $40 \mathrm{X}$ lens, however, has an attenuation factor of 5 after 2 hours exposure at the same intensity.

\section{Force-Reflecting Servomanipulators}

Several modifications were tried on a laboratory mockup of one motion for a 50-lb hydraulic servomanipulator. Performance was better than for previous hydraulic systems, but it is not yet adequate for manipulator application. The system stability was improved by a slight modification 
of the particular commercial valve used in this test. The viscous drag of the system was substantially decreased by redesign of the actuating pistons and by operation at higher pressure. Further work is in progress to replace the commercial valves with valves of more applicable design and lowe r cost.

A mockup of one motion for a 20-1b electric servomanipulator has been tested. The servo configuration of this system is similar to that of the Model 2 servomanipulator. Two motors of the same type are used at each end of the system and all four are controlled by a single magnetic amplifier. Performance is substantially reduced by the time delays associated with the magnetic amplifier. The addition of electrical networks to compensate for these time delays resulted in a system with less stiffness than that of the Model 2. Other compensating networks are being studied, and an electronic amplifier is being designed to replace the magnetic amplifier. 


\section{ASSOCIATED ENGINEERING AND DEVELOPMENT, 4600}

\section{A. Fluoride Volatility Process Research}

The hydrofluorination of $\mathrm{Zr}-\mathrm{U}$ in molten $\mathrm{NaF}-\mathrm{ZrF}_{4}$ can be monitored remotely by measuring the $\mathrm{H}_{2}$ evolution. In the molten salt process, fluorination of $\mathrm{UF}_{4}$ to $\mathrm{UF}_{6}$ is accomplished about equally effectively by $\mathrm{F}_{2}, \mathrm{BrF}_{5}$, or $\mathrm{ClF}_{3}$. After from 30 to $60 \mathrm{~min}$ of fluorination, less than $0.5 \%$ of the $\mathrm{U}$ remains in the salt. Corrosion of $\mathrm{Ni}$ in this system appears to be slightly accelerated by the presence of $U_{6}$ and corrosion products. In an experiment with irradiated, long-cooled alloy, $\mathrm{Nb}$ as $\mathrm{NbF}_{5}$ was carried out of the melt to the greatest extent of the fission products present. Construction and procurement of the semi-works dissolver and sparge unit has been started.

The existing pilot plant has been put through shakedown operations. It is planned to begin operating the plant by dissolving irradiated $\mathrm{U}$ in $\mathrm{BrF}_{3}$ and recovering decontaminated $\mathrm{UF}_{6}$ by fractional distillation.

Preliminary investigations have been started on the use of fluoride volatility for the recovery of $U$ from ore concentrates and from $\mathrm{MgF}_{2}-\mathrm{U}$ slags.

\section{B. Chemical Metallurgical Separations Research}

The shielded vacuum-casting furnace has been operated successfully on a kilogram scale with natural $U$ at pressures of 1 micron. A series of $\mathrm{Ru}-\mathrm{Mg}-\mathrm{U}$ alloys is being prepared. Later, the unit will be used for process research on radioactive materials.

Oxidative slagging of synthetic alloy, roughly equivalent to $1 \%$ burn-up, results in thick, tough slag. The yields of $\mathrm{U}$ for $2-\mathrm{kg}$ charges have consistently been about $90 \%$ as ingot. Re-use of crucibles gives better yields. In the investigation of liquid oxide slags, several unsuccessful attempts have made to prepare the $\mathrm{ZrO}_{2}-\mathrm{BaO}$ eutectic.

In the preparation of borided $\mathrm{Ta}$ as a container material for molten $U$, it has been shown that a layer of non-resistant $\mathrm{TaB}_{2}$ first forms. Upon further heating, some of the B diffuses through the Ta to form a lower boride which does not react with molten $\mathrm{U}$.

In liquid-liquid extractions of $\mathrm{Pu}$ from molten $\mathrm{U}$ by $\mathrm{Mg}$, a mole fraction distribution coefficient of 0.07 (preliminary value) was determined for $\mathrm{Pu}$ with a $0.1 \% \mathrm{Pu}-\mathrm{U}$ alloy fuel. Apparatus has been constructed to permit the $5-\mathrm{kg}$ scale study of $\mathrm{Mg}$ distillation as a method of recovering the extracted $\mathrm{Pu}$. 
Powdered $\mathrm{U}$ has been successfully filtered from molten $\mathrm{Mg}$. This technique will make it possible to investigate the diffusion of fission products and $\mathrm{Pu}$ from $U$, which may lead to a purification process. Solvents, such as molten halides, are being investigated for dissolving $\mathrm{UH}_{3}$ at moderate temperatures $\left(400^{\circ} \mathrm{C}\right)$. The properties of metal hydrides differ appreciably; this fact may lead to another separations system if a satisfactory solvent can be found.

\section{Fluidization Studies}

Denitration of uranyl nitrate solutions to $\mathrm{UO}_{3}$ in the 6 -in. fluid bed unit at $525^{\circ} \mathrm{C}$ did not produce a significant change in the reactivity of the $\mathrm{UO}_{2}$ when compared to material denitrated in the same unit at 300 to $350^{\circ} \mathrm{C}$. Laboratory results at the $\mathrm{K}-25$ plant of Carbide Nuclear Company indicated that there was an appreciable improvement. The difference may be caused by cooling from dehydration in the spray zone of the fluid bed so that denitration actually occurs at a temperature well below that of the bed.

Batch operation of fluidized-bed hydrofluorination of $\mathrm{UO}_{2}$ toUF 4 required temperatures in excess of $390^{\circ} \mathrm{C}$; the $\mathrm{UF}_{4}$ did not sinter at $575^{\circ} \mathrm{C}$, the highest temperature investigated.

The hydrogen reduction step was demonstrated on a continuous basis for 7 hours at $575^{\circ} \mathrm{C}$ in the 3 -in. diam fluid bed unit. The product assayed approximately $96 \% \mathrm{UO}_{2}$ after an average residence time of $5 \mathrm{hr}$. Hydrofluorination was similarly demonstrated for $12 \mathrm{hr}$ at $450^{\circ} \mathrm{C}$. There was approximately $94 \%$ conversion to $\mathrm{UF}_{4}$, which is acceptable for $\mathrm{UF}_{6}$ production. Re-hydrofluorination of this material under the same conditions raised the conversion to about $98 \%$, which is acceptable for metal conversion.

\section{Process Waste Disposal and Utilization}

Prelininary design has begun on a fluidized bed reaction vessel to be installed in a shielded cell for calcining radioactive liquid wastes. The first plans for the unit call for dehydrating and denitrating $\mathrm{Al}\left(\mathrm{NO}_{3}\right)_{3}$ solutions typical of certain solvent extraction wastes to give solid $\mathrm{Al}_{2} \mathrm{O}_{3}$. 